University of Rhode Island

DigitalCommons@URI

Open Access Master's Theses

1993

\title{
INDUSTRIAL SITE SURVEY FOR THE TOWN OF WESTERLY, RHODE ISLAND
}

Thomas L. Quattromani Jr.

University of Rhode Island

Follow this and additional works at: https://digitalcommons.uri.edu/theses

\section{Recommended Citation}

Quattromani, Thomas L. Jr., "INDUSTRIAL SITE SURVEY FOR THE TOWN OF WESTERLY, RHODE ISLAND" (1993). Open Access Master's Theses. Paper 566.

https://digitalcommons.uri.edu/theses/566

This Thesis is brought to you for free and open access by DigitalCommons@URI. It has been accepted for inclusion in Open Access Master's Theses by an authorized administrator of DigitalCommons@URI. For more information, please contact digitalcommons-group@uri.edu. 


\section{INDUSTRIAL SITE SURVEY \\ FOR THE TOWN OF WESTERLY, RHODE ISLAND}

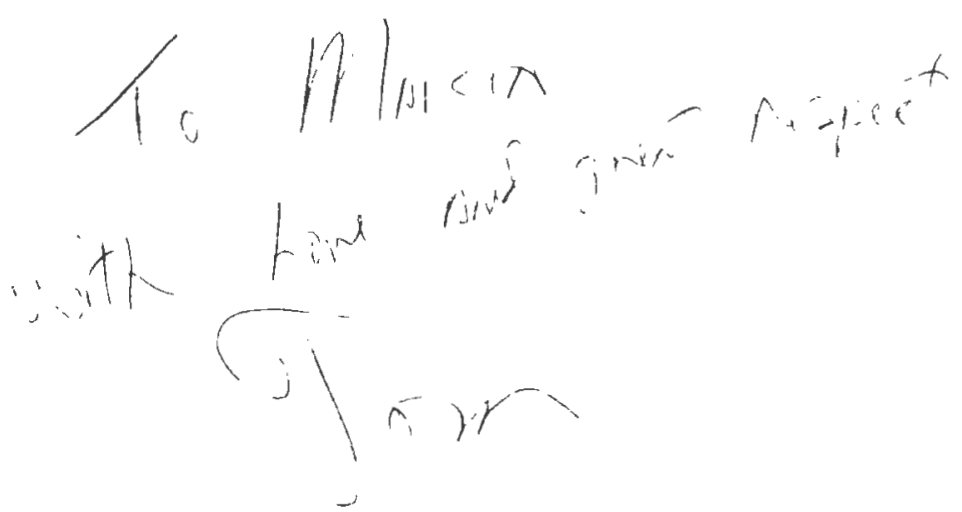

Submitted by:

Thomas L. Quattromani, Jr.

Submitted as a Master's Research Project in

Partial Fulfillment of the Requirements for the Degree of

Masters of Community Planning

University of Rhode Island

1993 
MASTERS OF COMMUNITY PLANNING RESEARCH PROJECT

SUBMITTED BY:

THOMAS L. QUATTROMANI, JR.

APPROVED:

MAJOR PROFESSOR Hern un Mule Feed

ACKNOWLEDGED:

DIRECTOR

Morea Mach u Held 
TABLE OF CONTENTS .................. i

LIST OF FIGURES $\ldots \ldots \ldots \ldots \ldots \ldots \ldots$ iii

LIST OF TABLES $\ldots \ldots \ldots \ldots \ldots \ldots \ldots \ldots$ iv

INTRODUCTION

Page
1
2

I. DEVELOPMENT OBJECTIVES AND INITIAL SITE SELECTION

Introduction

4

Site Identification

4

Industrial Site Location Criteria 6

Initial Search for Sites 12

Site Vicinity Description 14

Site One: $\quad 15$

Site Two: $\quad 16$

Site Three: 17

Site Four: $\quad 18$

Site Five: $\quad 19$

I I. INITIAL SITE EVALUATION

Introduction 21

Site One: $\quad 23$

Site Two: 25

Site Three: 25

Site Four: 26

Site Five: $\quad 27$

III. INVENTORY AND SITE ANALYSIS

Introduction 29

Inventory and Site Rendering 33 
IV. SITE EVALUATION AND SECLECTION

Introduction 34

Criteria

Final Site Rating $\quad 38$

V. Conclusion and Recommendations

Conclusion 42

Recommendations Introduction 43

Industrial Park Development Recommendations 44

Recommendations for Other Issues 49

\section{APPENDIX}

List of Property Owners by site

Bibliography 


\section{LIST OF FIGURES}

Page

Figure 1.1 General Location of Initial Sites 12

Figure 1.2 Identification of Potential Industrial Sites
12

34

34

34

34

34

51

51 


\title{
LIST OF TABLES
}

\begin{abstract}
Page
Table 1.1 Factors Viewed "As Must" for Site Selection

9

Table 1.2 Ten Most Important Location Factors ranked by 162 companies

10
\end{abstract}

Table 4.1 Site Evaluation by Sixteen Criteria 35

Table 4.2 Comparison by Individual Criteria 36

Table 4.3 Site Ranking by Individual Criteria 37

Table 4.4 Summary Table 37 


\section{Introduction}

During the last ten years, the Town of Westerly, RI along with the entire New England area has experienced a downward trend in manufacturing employment. In addition, Westerly has become aware of the need to prepare for the possible closure or intercontinental move of one of Southeastern New England's largest employers, General Dynamics located in New London, Connecticut. General Dynamics represents Westerly's largest single employer with $10 \%$ or 1,000 Westerly residents employed directly and a higher unknown percentage employed in associated industries, which would be impacted by significant changes in the regional economic base.

The Town's 1992 Comprehensive Plan does not address the issue of downward employment trends in manufacturing and was written before the potential loss of General Dynamics became apparent. The Westerly Economic Development Board, however, has been meeting regularly to access the implications of such loses and to review remedial options. For example, Westerly has taken two major steps. First, the Town of Westerly's Economic Development Board has requested that an industrial site survey be conducted to identify suitable industrial space within the town's limits.

Second, the Economic Development Board is studying Westerly's current relationships with neighboring towns in an effort to integrate individual programs into an enhanced regional planning effort. This association has developed into an organization called the Southern 
Rhode Island Economic Coalition, comprised of the townships of Hopkinton, Richmond, Exeter, Charlestown and Westerly. Together, the towns have started to address issues such as the loss of defense related industries and the steady local decline in manufacturing employment.

For the purpose of this study, the definition of industrial use will extend beyond the traditional manufacturing activities normally associated with industrial use. Rather, the term industrial will be broadened to include additional activities found in contemporary industrial parks such as research centers, office facilities, and distribution centers.

GOALS OF THIS STUDY

Recognizing the need for a more focused and detailed analysis of industrial site potential, the goal of this research study is to identify areas within which the town might attract growth industries that would make use of workers which match Westerly's labor force profile. To accomplish this goal, this report will systematically perform an analysis process consisting of four phases or steps that will lead to the identification of the best sites for industrial uses in the Town's borders.

The four elements of the analysis process are as follows: Phase 1. Application of a broad set of criteria to identify and compile a 
selection of initial sites. Phase 2. Use of a more restricted set of criteria which eliminate sites with obvious constraints. Phase 3. examine and inventory of site characteristics. Phase 4. Evaluation and selection of most suitable site based on its overall relationship to the criteria and its comparative ranking to the other sites. This study will conclude with a series of recommendations to act as strategies for the development of an industial park on the most suitable sites and provide recommendations on other pertinent issues that need to simultaneously be examined for Westerly to obtain its' share of future economic development in Rhode Island. 


\section{CRITERIA DEVELOPMENT AND SITE IDENTIFICATION}

In the first phase of this study, a broad set of criteria for site location was developed. The criteria was based on interviews with the Westerly Economic Development Board, telephone interviews with staff members of Rhode Island's Department of Economic Development research division and a literature review. The purpose of this phase is to use a broad set of criteria to identify and inventory sites which appear to have potential for supporting industrial development. In this section, the fundamental criteria for initial site selection will be developed. Once the basic criteria is developed, they will be used to create a list of potential sites. Subsequent chapters will give a critical evaluation of potential sites to determine their actual capacity to support economic development.

\section{Site Identification Methods}

According to literature of industrial location theory, there are two standard approaches used to identify potential industrial areas, the "Blue Ribbon Commission" approach and the "Comprehensive Planning Approach"1. The "Blue Ribbon Commission" approach is usually made up of a formally appointed commission that consists of community members that have an interest and basic awareness of the economic, social and natural characteristics of their community. In the case of Westerly, a commission has not been created to

1 Stafford, Howard A. (1980) Principle of Industrial Facilities Location (Atlanta: Conway Publication, Inc.) 
specifically locate an industrial site, therefore the Economic Development Board, has in effect become the "Blue Ribbon Commission".

The second standard approach is the "Comprehensive Planning Approach", which is used to identify potential sites that satisfy a list of criteria set by experts in state agencies and from technical literature. This method tends to be rational with criteria based on scientific analysis which measures variables such as distance to markets and access to highways, etc.

The difference between the two approaches is one of emphasis. For example, the "Blue Ribbon Commission" approach is more sensitive to local social and political factors that need to be addressed, while the more rational "Comprehensive Planning Approach" uses criteria that are scientifically and economically based. This study has used a combination of both approaches, by utilizing the knowledge and experience of the Westerly Economic Development Board and by using technical factors from the "Comprehensive Planning Approach" such as soil types, access to highways and municipal services in a rational analysis.

The result of using both methods simultaneously is the development of a set of basic industrial location criteria which was then applied to a mapping analysis of candidate sites within the study area. This mapping analysis produced a small list of sites in the town which satisfied the basic site selection criteria. 


\section{Industrial Site Location Criteria}

The industrial location criteria used in this study were established through interviews with the Westerly Economic Development Board (EDB), telephone interviews with staff members of Rhode Island's Department of Economic Development (DED) and a literature review on industrial location decisions. While these sources were in agreement as to the basic criteria, they differed in the emphasis that is placed on individual factors in a decison making process. For example, the Westerly EDB suggested criteria which they believed reflected the town's needs and desires. The criteria given through interviews with DED and a literature review emphasizes the needs and desires of industries that are searching for new industrial sites.

The EDB's criteria focused on the need to minimize community impacts. These were: the need for sites to have a minimal capital improvement cost; low impacts on residential and commercial zones, and a need to restrict traffic generated to major arterial roads. The Rhode Island DED and a widely used study of industrial location choices written by Roger W. Schmenner, Making Business Location Decisions (1982), reflect two types of criteria. The first type of criteria is used by industries to locate regions within the country and includes factors such as the quality of life, climate, labor factors and market proximity. The second type of criteria locates specific sites within a region and is used to identify sites with rail and highway 
access, and other infrastructure support facilities like sewer and water availability.

Four key criteria, DED's research division identified are:

- $\quad$ Easy access to major transportation facilities

- High roadway visibility

- $\quad$ All utilities available

- Available labor market

DED's short list of important factors highlights the priority that industry places on access to transportation facilities such as highways, rail roads and shipping ports. The importance of utilities was the second criteria highlighted by DED. Industries want to be serviced by municipal sewers and water as well as have access to a reliable electrical and or gas power source. The third criteria was that industries want a readily available labor market to fill technical and managerial positions in new plants. Finally, DED gave the criteria of good highway visibility which would be irrationally based for industries selling their products internationally or outside the region. Good highway visibility could be rationally based if it is considered to be important by industries with local markets or for the ease of raw material suppliers, business associates and employees trying to locate the facility from the highway.

With the only difference being the emphasis placed on individual criteria, common criteria from the EDB, DED and literature sources such as Schmenner (1982) were selected to become the broadly 
based criteria used to create a list of potential industrial sites. The broadly based criteria used to create a first list of potential sites in this study were:

- $\quad$ Easy access to Highways

- $\quad$ All utilities available

- $\quad$ Sites adjacent to arterial roads

- A minimum of 25-50 acres

Access to highways and utilities, are criteria used in this study which are complementary to those found in Schmenner's 1984 survey of Fortune 500 companies (Table 1.1), as well as in a study conducted by Howard Stafford, Environmental Protection and Industrial Location (1985), where Stafford surveyed 162 American firms (Table 1.2).. In Schmenner's 1984 survey of Fortune 500 companies, Schmenner was trying to ascertain the most important criteria industries use while identifying and ranking new locations for industrial expansion. Stafford's 1985 survey was conducted to show the effects of environmental regulations on industrial location decisions. Although Stafford's survey did not specifically try to identify the most important criteria that executives use to identify and rank sites in location decisions, his survey was comprehensive enough to illustrate the relationship between location factors.

Table 1.1 shows the results of Schmenner's 1984 mailing survey, where executives were asked which factors they considered as the most important in location decisions. The results of this survey shows that access to rail service, highways and utilities are ranked 
the top three criteria. The fourth ranked criteria "rural area" indicates the desire of industry to locate in rural areas, characteristic of many parts of Westerly, for a more pleasant and enjoyable working and living environment. Table 1.2 derived from Stafford's survey, ranked transportation facilities second and dependent factors such as nearby markets, raw materials and infrastructure as the third and fourth most important factors in location decisions.

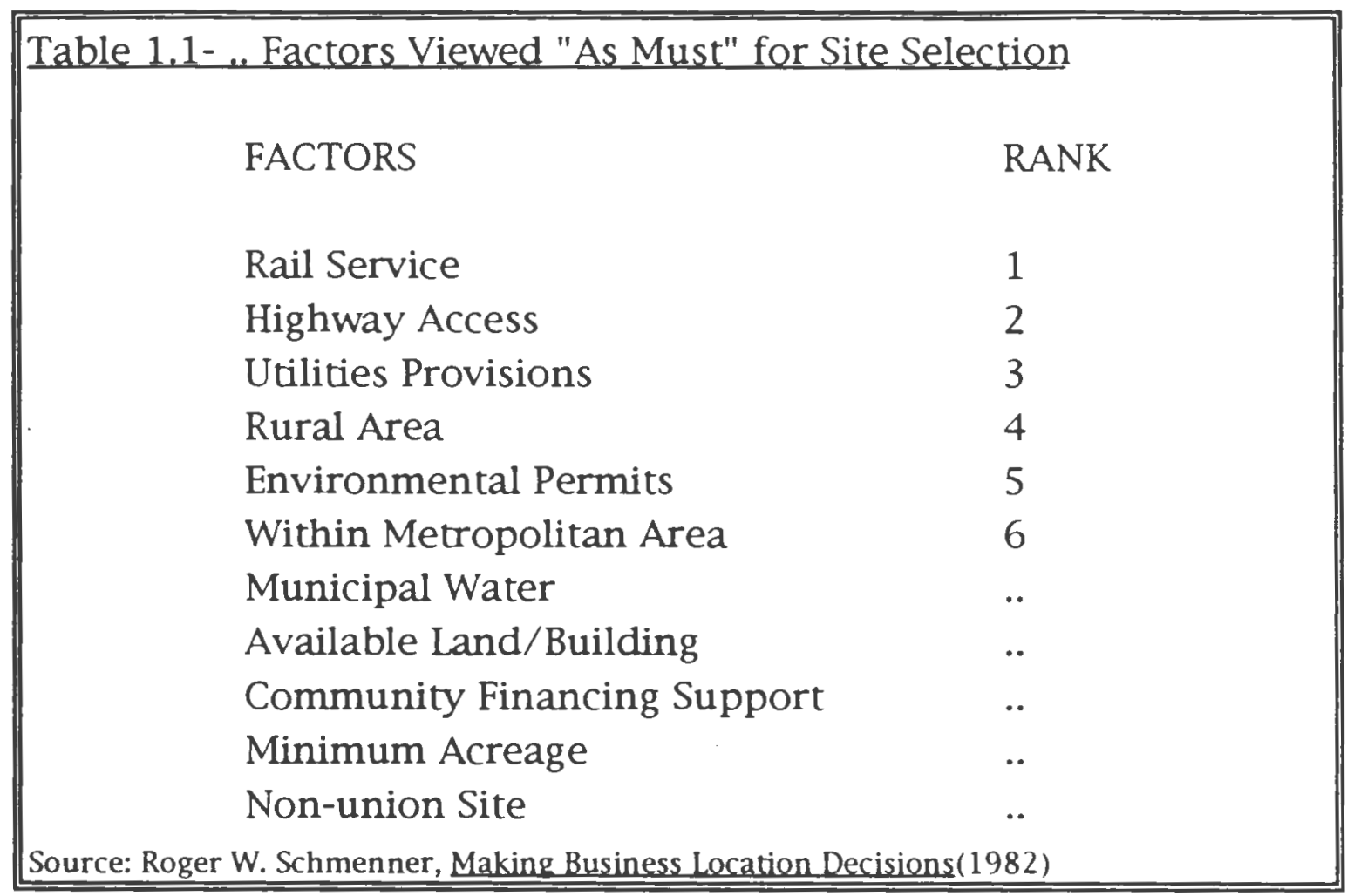

Table 1.1 , notes that access to both metropolitan and rural areas was considered as one of the more important factors. The significance of the ranking shown in Table 1.1, is the implied advantage of highly developed transportation facilities in an industry's site selection process. This might be based on the need to travel to and from metropolitan and rural areas. 
The significance of transportation systems is also apparent in Table 1.2, which shows transportation ranked second and other factors that are dependent on transportation systems like labor, markets, raw materials and supplies as also ranking high. All such factors need transportation systems to travel from different areas of a region and the immediate surrounding areas.

Table 1.2 Ten Most Important Location Factors ranked by 162 companies ( $1=$ highest $)$

FACTORS

Labor

Transportation

Markets

Raw Materials and Supplies

Utilities \& Infrastructure

Quality of life

Business Climate

Site Characteristics

Community Characteristics

Taxes $\underline{\text { RANK }}$

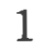

2

3

4

5

6

7

8

9

10

Source: Howard Stafford (1985) "Environmental Protection and Industrial Location"

The results of these two surveys completed by Schmenner and Stafford correspond with the first two broadly based criteria utilized by this study. The need to travel to and from different areas of a region and the immediate surrounding, by employees, raw materials and finished products lead to the third basic criteria suggested by the EDB. The EDB suggested that the location of potential sites be 
restricted to areas adjacent to arterial road networks. Their suggestion is consistent with suggestions from staff members at DED.

Finally, the last criteria was established despite a difference concerning the importance of site size, between the EDB and DED on one hand and Schmenner and Stafford on the other. Both the EDB and DED suggested that site size be a minimum of 25-50 acres. The minimum size was justified by the EDB and DED, due to the capital cost involved in extending sewer, water and electric line and improvements to roads and intersections.

Schmenner's and Stafford's surveys appear to illustrate that site size is not very important to executives in the location decision process. This occurrence is the result of two main factor. The first factor is that different types of industrial uses need different size lots. Their surveys covered a wide range of industrial types, so the importance of site size is probably under estimated. The second factor is the grouping of site size with other over riding factors like transportation facilities. While considering the general location of a site with in a region, an executive would consider transportation first. Then after a general location with access to transportation facilities has been identified, site size becomes important in choosing between sites in that location. Therefore, site size can be considered as a factor that is secondary and oriented towards ranking sites in close proximity identified by a previous examinations with criteria like transportation facilities, which is oriented toward ranking larger areas in which smaller sites can then be ranked. 

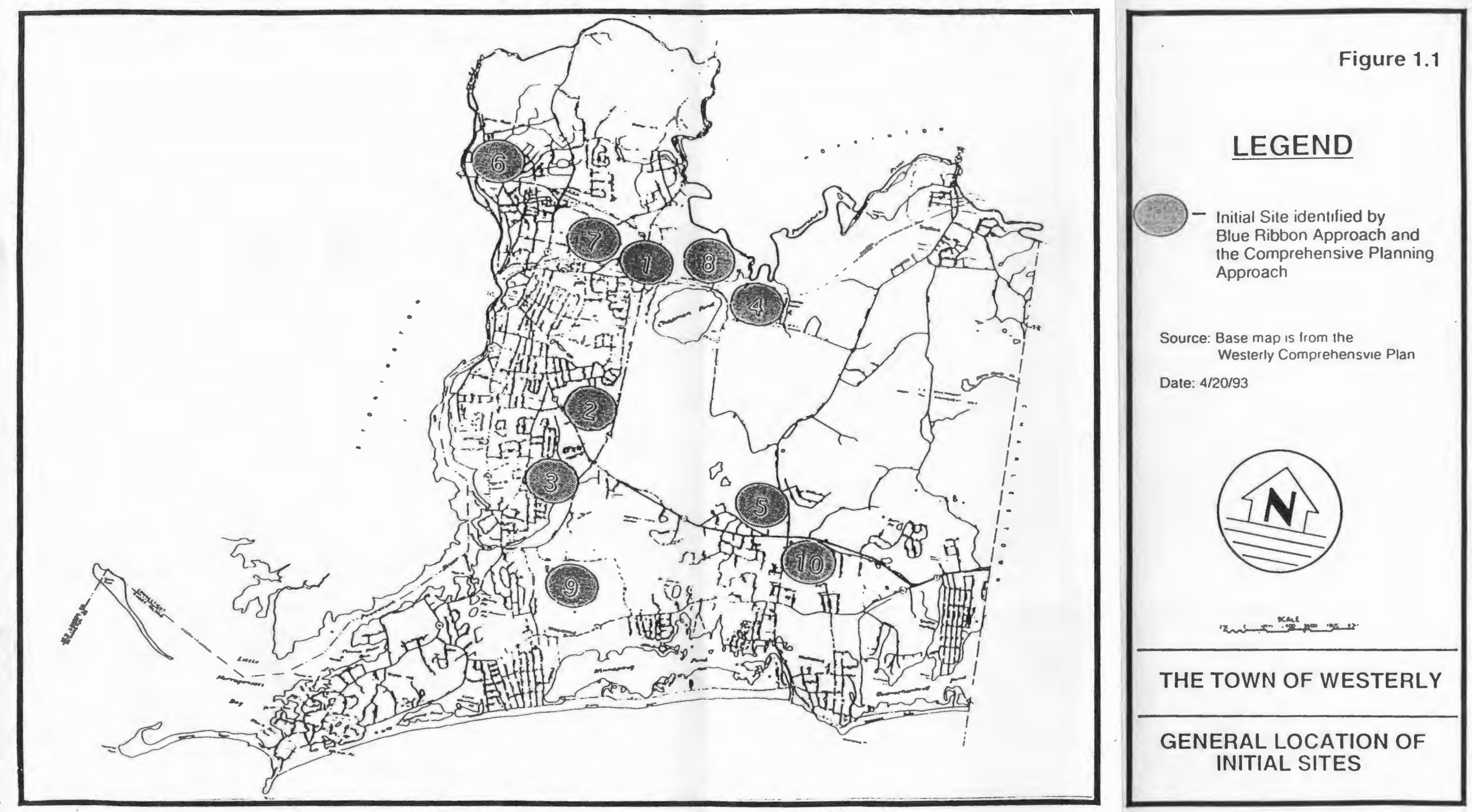

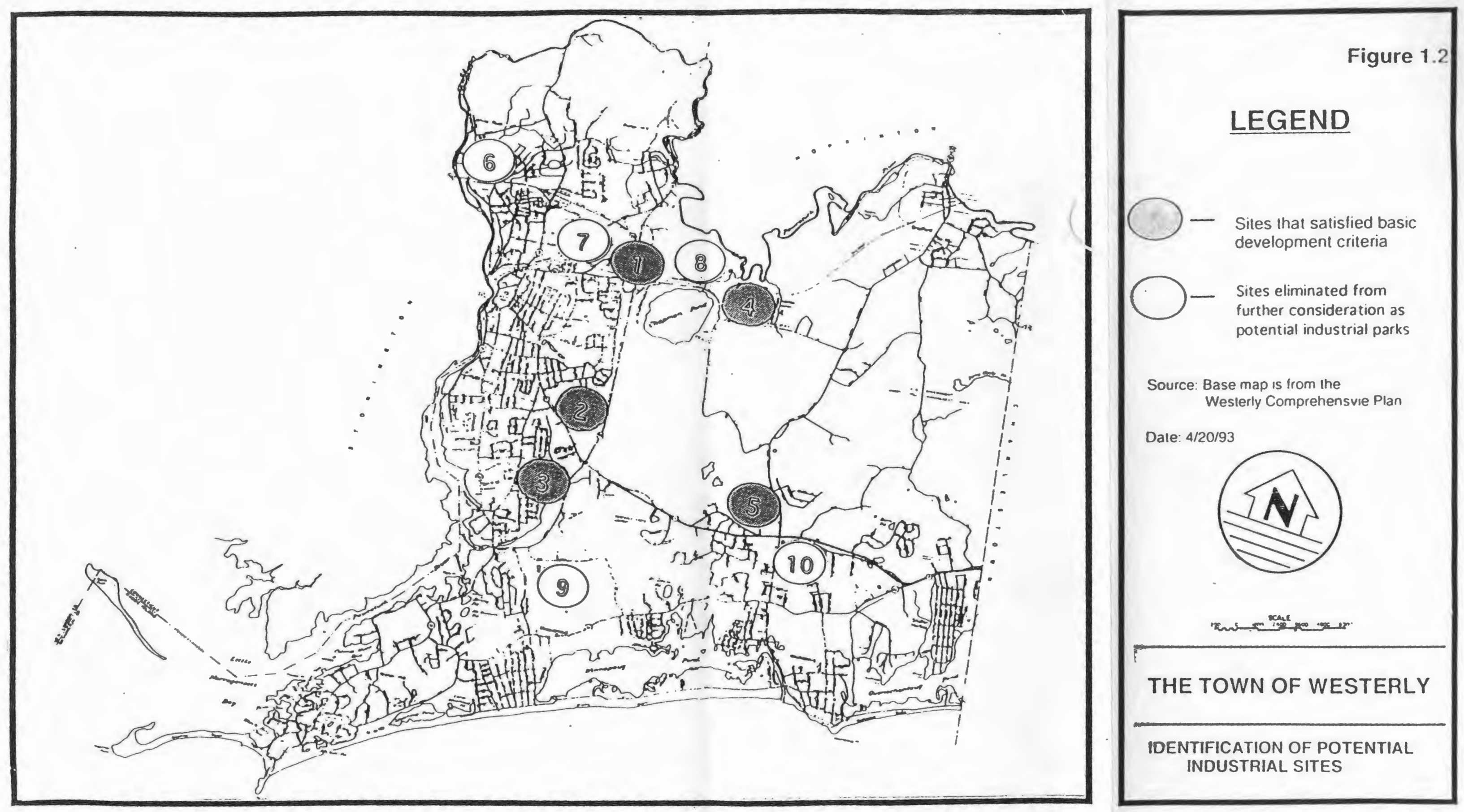


\section{Initial Search for Sites}

By combining the "Blue Ribbon Approach" and the "Comprehensive Planning Approach", a search within the Town's limits was conducted. The main development areas of consideration were adjacent to highways such as Route 1 and Route 78 and arterials such as Airport Road and the Westerly - Bradford Road as shown in Figure 1.1 with heavy lines. This search lead to the identification of ten sites that could now be considered as potential industrial sites, if they satisfied the basic criteria of highway and utility access, serviced by arterial roads and the site must be at least a minimum size of 25 to 50 acres.

Five of these sites were eliminated from further consideration for failing to comply with the basic criteria because of a variety of reasons(See Figure 1.2). The first site to be eliminated was Site Six along White Rock Road, behind a Town recreational area. This site had marginal access to highways, due to the necessity of traveling through Canal Street which itself is 10 feet wide and has substandard shoulder widths. The portion of the site with street frontage is currently being used as a playground and recreational area. The site is also near Westerly's main water pumping stations.

The second site is located on the northern side of Old Hopkinton Road. This site has been eliminated from further consideration, because the site has a high percentage of its acreage restricted from 
use by steep slopes and is also used by several residential homes. The third site eliminated from consideration is on the northern side of the National Railroad Passenger Corridor operated by Amtrak as the main rail line from Boston, Massachusetts to Washington DC.. This site was eliminated, because the nearest road was a .25 miles away and the property is $95 \%$ wetlands and hydric soils. The fourth site eliminated from further consideration was located across the street from Westerly's only existing industrial park on Tom Harvey Road. This site is currently being developed for high income residential homes. The site also has a high percentage of steep slopes and the soils are classified by the Soil Conservation Manual as having large stones.. These characteristic make the developability cost prohibitive for erecting industrial sites, that need large flat strips of land.

The fifth and last site that was eliminated was in the area known as Dunn's Corners. This lot has currently been cleared and is now being developed. The site has also been eliminated because the size of the lot is under 20 acres and is bounded by residential complexes.

After five of the original ten sites were eliminated due to failure to satisfy the four criteria established in this study, five remained. Two of the sites are located within areas identified by the Westerly Comprehensive Plan as appropriate for industrial land use. Similarly, one site is located in a commercial area, and the last two are located on land presently zoned for agriculture. Each 25 to 50 acre site consists of individual parcels greater than 5 acres. This minimum 
acreage requirement was established so that the largest amount of acreage could be accumulated for development.

Consistent with the initial site criteria, the five remaining sites were chosen because of their proximity to major transportation routes throughout the town, availability of utilities, and a site size minimum of 25-50 acres. The general site locations are shown in Figure 1.2. The site locations are as follows:

Site One: Old Hopkinton Road

Site Two: Route 1 and Route 78

Site Three: Airport Road

Site Four: Route 91

Site Five: Route 1 and Westerly Bradford Road

\section{Site Vicinity Description}

The plat and lot number for each parcel was used to identify the property owner and parcel size from the chain of custody file. The current zoning requirements for each of the lots was determined from the Town's Official Zoning Map and verified by records in the Westerly Tax Assessor's Office. Parcel data for each site are included as appendix " $\mathrm{A}$ ". The following descriptions contain a general summary of site conditions and parcel data. 
Site One: Old Hopkinton Road

Site One is located in the Northern section of Westerly. The site can be reached by traveling Route 91 east onto Old Hopkinton road or by exiting Route 78 onto Route 91 west for half a mile to Old Hopkinton Road. The site has good access to highways and major arterial roads with Route 91, .25 miles away and Route 781 mile away. Access to utilities is available with water and sewer lines approximately .1 miles west on Old Hopkinton Road and .25 miles west on Rout 91.

The site is surrounded by several different land uses, such as the main National Railroad Passenger Corridor to the south and a mix of residential and industrial uses to the north. The National Railroad Passenger Corridor is Amtrak's main rail line from Boston, Mass. to Washington, DC. Site 1 is separated into two separate sections by Route 78 and is separated from the residential and industrial uses to the north by Old Hopkinton Road. In addition to Westerly's largest marsh bordering the eastern side of the site, there are also two small marshes and ponds located inside the western half of the site.

The site is sparsely wooded, with gentle slopes. Most of the site is located on soil type UR, which the Soil Conservation Service classifies as urban development filled in by man for some commercial or industrial purpose.

The entire site is comprised of 8 parcels, totaling 86.43 acres. The 8 parcels are currently categories by the Westerly Tax Assessor's 
Offices as having several different uses. Two of the sites hare currently classified as vacant parcels. Of the remaining six parcels, one is currently used by the town for it's Pee Wee Football Field, one parcels is currently a multi-family residence, another is used as commercial space and the remaining two parcels are currently used for industrial purposes.

Site Two: Route 1 and Route 78

Site Two is located behind the Almacs Shopping Plaza .25 miles west of the Route 1 and Route 78 intersection. The site has very good access to Route 1 and Route 78 which are .18 and .25 miles way from the site respectively. Utilities are available through connections with sewer, water and electric lines adjacent to Route 1.

This site is bounded to the northwest and north by residential neighborhoods and vacant parcels. The eastern section of the site is bounded by the Route 78 by-pass, with no direct access routes from the site to the by-pass. The southern section of the site is separated from Route 1 by commercial complexes and residential homes, however, a right of way provides a direct access point to the site.

The site is mostly covered by farm land with some hydric soils in the western portion and upper middle portion of the site including two first order streams. The site is classified as rolling terrain with no steep slopes. The site is 84.80 acres in size. 
Site Three: Airport Road

Site three is located .05 miles south of the Route 1 and Route 78 intersection. The site extends westward to East Avenue and south to a state recreational area. Despite the sites isolation from the downtown area and the commercial development of Granite and Franklin Street(sections of Route 1), the site has good access to highways with the above major intersection a short distance away. Utilities are also very accessible, with all utilities currently adjacent to the eastern edge of the property under Airport Road.

Site three is adjacent to a contiguous residential use on three sides of the site. To the west, the site is mostly bounded by residential homes, but includes an access route to a minor arterial called East Avenue. To the north, the site is bounded by residential homes and a right of way to Route 1. Airport Road extends the entire length of the eastern portion of the site, with a right of way extending several hundred feet across a portion of the northern boundary. To the south of the site is a recreational area and state owned conservation area.

The site consists of 137.9 acres. Open farmland makes up the highest percentage of the site, with wooded areas in and around the site mixed in. There are two streams that transverse the site from the north and east that proceed near the eastern side of the site down to the southern end. Three owners hold rights to the majority of this 
site. One holds the larger southern parcel which makes up about 77 acres, another owner holds a portion in the middle which comprises 33.36 acres and the last owner retains rights to the rest of the site.

Site Four: $\quad$ Route 91

Site Four is located 1.17 miles east of the Route 91 and Route 78 interchange. This site is the mọst isolated site from the urban areas of Westerly. Despite the sites isolation from the downtown area and the commercial development of Granite and Franklin Street, the site has good access to highways. The site has road frontage on Route 91 which travels either west to Route 78 or east to Route 216 . Both connecting routes lead to Interstate 95 , which is the main interstate highway traveling north and south.

Municipal utilities such as sewers and water are not available for this site, however the site is suitable for Individual Sewage Disposal Systems (ISDS) and wells in that area have 50 to 100 feet of outwash from which to draw water. The site is over Westerly's most important aquifer recharge area, therefore strict standards will have to be included into the ISDS designs for complexes on this site.

Site four is bounded to the north by the National Railroad Corridor and Route 91 to the west and south. The eastern section of the site is bounded by vacant farm land property that mainly consists of wetlands and hydric soils and one residential home. The wetlands 
cross the eastern border into the site. Vegetation on the site is scarce, because farming was the historic use of the land. The terrain is described as level with minor changes in elevation.

Site Four is a 97.6 acre area with 8 property owners with 9 parcels of land. Of the 9 parcels, 5 are developed as residential homes. The remaining 4 lots comprise 71.5 acres of the overall site. One lot, which is listed as farmland, is the largest of all with 60.9 acres of land. The last three parcels consist of a 6.2 acre farm and two vacant lots 4.3 acres in sizes.

Site Five: Intersection of Route 1 and Westerly Bradford Road

Site Five is located in the area known as Dunn's Corners. This is where Route 1 and the Westerly-Bradford Road intersect. The site had good access to Route 1 which intersects Route $78,2.17$ miles to the west. Like site four, this site has no access to municipal sewage, however, careful design of septic systems will protect the sensitive aquifer recharge area of which it is a part. Access to municipal water is available from water lines along Route 1 and the WesterlyBradford Road.

The site is separated from Route 1 by several commercial and residential uses to the south. The site is also separated from the Westerly-Bradford Road by the same uses to the east except further north where the site has road frontage on the Westerly-Bradford Road. To the north the site is bounded by Pound Rd and wetlands. 
The site is comprised of 9 parcels with different owners and sites ranging in size from .8 acres to 110 acres for a total of 214 acres. This is the largest of the five sites, however almost 100 acres are unusable due to wetlands and residential uses. 


\section{INITIAL SITE EVALUATION}

The first chapter identified sites which initially appeared to be suitable for supporting economic development. The selection was based on the general location criteria suggested by the Westerly Economic Development Board, Rhode Island Department of Economic Development and a literature review. As was mentioned earlier, initially a broad set of criteria was used to identify the largest number of potential sites within the town. As a result of this method, five sites have been located and a general overview has been given for each site.

In chapter II, the five initial sites will be examined more closely for their industrial development potential. The actual boundary limits of each site will be defined and sites or parts of sites which have obvious and critical limitations for supporting appropriate industrial development will be disregarded from further study.

The site limitation criteria that will be used to eliminate sites will include accessibility, site constraints and utilities. An industrial development site should be adjacent to or have the ability to access a major transportation roadway. Sites which did not have frontage on a major roadway and can only be accessed by local residential streets were considered to have severe access constraints, because of the danger to residents and capacity limitations of local roads on large trucks. 
Site constraints include environmental site limitations such as wetlands, slopes greater than 15 percent, hazardous waste or conservation easements. This category also applies to sites which are currently developed with residential homes, large recreational or public use areas. These constraints hamper development in several different ways. First, any alteration of wetlands requires the obtainment of several permits from agencies like the Department of Environmental Management and the Environmental Protection Agency. The process of obtaining permits will delay the development of any project by at least four to six months.

Slopes greater than 15 percent present severe problems that have to be directly address and designed for. Steep slopes during construction have a high potential for run-off and erosion problems that must be prevented. Testing for hazardous waste has to be implemented before construction of any large project begins, because state and federal laws such as the Comprehensive Environmental Response Cleanup Act and the Superfund Authorization Act requires that current property owners clean up all hazardous waste regardless if they placed the waste on the site or not.

The literature review performed for this report revealed that the availability of municipal sewers and water were found to be extremely important while comparing sites within a region. In this report, water and sewer access were considered available when either provided by a municipal source or by private wells and septic systems. Sites that were not serviced by municipal water and sewer 
and not capable of providing their own sources, were considered to have severe limitations.

All of the parcels which compose each of the five sites identified in Phase I were plotted from a composite of Westerly's Tax Assessors Maps. Each parcel was then labeled by its existing land use according to the standards of residential, commercial, industrial, conservation, public land and vacant land. This resulted in an inventory of vacant lots per site and the number of residential homes that might pose a severe constraint.

At this point in the project, the main criteria which will be examined are accessibility, utility availability and site constraints. The following descriptions of the initial sites will further evaluate the sites.

Site One: Old Hopkinton Road

Site One is made up of two separate parcels called $1 \mathrm{~A}$ and $1 \mathrm{~B}$. The two parcels are separated by Route 78 , which is 20 to 30 feet higher in grade than both parcels.

Site 1A was eliminated from consideration as a potential industrial site because of site constraint factors. The site has good access to both highways and public utilities, however site 1A has a shortage of vacant acres on which to build a park. Site 1A consists of about 28 acres with only two vacant lots comprising 7.86 acres. Of the other 
six lots, one is currently a two-family residence on 4 acres of land. This lot has an access right of way which separates a 5 acre parcel, which is currently used as the Town's Pee Wee Football field, from two abutting lots currently used for industrial purposes. These abutting lots are already operating in an industrial capacity, so it is hard to justify the disruption of those activities. Finally, the last three lots combined are about 7.8 acres in size which is insufficient for the placement of an industrial park.

Site $1 \mathrm{~B}$ satisfies the general criteria for further consideration as a potential industrial site. This site is made up of one parcel of land 56.58 acres in size that has good access to arterials with Frontage Road acting as an access road from Old Hopkinton Road. The site is located within easy access of Route 91, Route 78, Route 1 and ultimately I- 95. The distance form the site to those highways are .25 miles, .5 miles, 2 miles and approximately 3.5 miles respectively.

Several commercial properties on the western side of the parcel may be added to the site to eliminate complaints of noise from heavy vehicles traveling Frontage and Old Hopkinton Road. Both water and sewer are potentially available to the site from connections less than a tenth of a mile west on Old Hopkinton Rd and a quarter of mile away on Rout 91. 
Site Two: Route 1 and Route 78

This site satisfies the general criteria for further consideration as a potential industrial site, because it has good access to highways, utilities and is a large site. This parcel is 84.80 acres in size, currently vacant and zoned for commercial use. Soils on the site are considered satisfactory ${ }^{2}$, except for 23.3 acres of the site which are hydric soils. The 23.3 acres of hydric soils are in three locations on the site, but will allow for the design of one continuous site.

The western edge of this site is 760 feet from both municipal water and sewer lines on Franklin Street(Route 1). Access to highways is directly available, due to a right of way connecting the site to

Route 1 . Visibility to the site is good from Rt. 78 which bounds the eastern side of the site.

Site Three: Airport Road

Site three qualifies for further consideration as an industrial site, because of it has good access to highways and utilities and is a large site.. The site is 137.96 acres in size and consists of six parcels. Two of the parcels had to be eliminated, because of homes on the site. Site three also loses 35.46 acres to hydric soils, which follows two streams traversing the site from the northern and eastern side of the site, down through the southern boundary of the property. With the

2 Rhode Island Soil Conservation Manual 
subtraction of the residential homes and the hydric soils, site three is still 96.5 acres in size.

Site three has direct access to Airport Road which intersects Route 1 and Route 78. The site also has two other access points, one is through a right of way on the western side which provides access to East Avenue. The second access point is through another right of way on the northern side which provides access to Route 1 . Site three also has access to both municipal sewer and water. Both services are available through lines under Route 1 and Airport Road.

It should also be noted that even though the 1992 Westerly Comprehensive Plan does not specifically address the need for industrial development as a means to offset employment loses, it does mention that site three is a special district ${ }^{3}$. The Plan continues to mention that this site merits investigation for possible manufacturing uses, because of its close proximity to other industrial uses and the availability of municipal sewer and water services.

Site Four: Route 91

Site Four qualifies for further consideration as a potential industrial site even though it does not have access to utilities, because it has access to a railway and highways and is a large site. This site consists of 53.49 acres after residential and hydric soils are

31992 Westerly Comprehensive Plan 
subtracted from the original total acreage of 97.6. The site has direct access to Route 91 which intersects with Route 78.

The site lacks municipal sewer and water, however the site is located over 50 to 100 feet of outwash, which means that a well can be used to supply water for an industrial complex. The soil is suitable for the disposal of sewage with the use of septic tanks and leach fields. ${ }^{+}$

Site Five: Intersection of Route 1 and Westerly Bradford Road

Site Five qualifies for further consideration as a potential site for an industrial park even though it also does not have access to utilities, because it has access to highways and is the largest potential site in Westerly. Access to highways is good, with a right of way connecting the southern portion of the site to Route 1 and road frontage along the Westerly-Bradford Road. The Westerly-Bradford road intersects Route 1 and also travels north toward interstate 95.

Municipal water is directly available from lines running along Route 1 and the Westerly-Bradford road. Municipal sewage is not available, however the site has suitable soils for the design of individual septic disposal systems. 5

4 Rhode Island Soil Conservation Manual

5 Rhode Island Soil Conservation Manual 
Two lots were eliminated from Site Five, because of severe limitations due to residential homes on the lots. This results in a minor lose of 1.8 acres. A more significant lose of 97.1 acres is due to hydric soils which cross the western section of the site. Although the lose of almost 100 acres of this site may seem significant, it should be noted that 114 acres of suitable land is still available. 


\section{INVENTORY AND SITE ANALYSIS}

In Phase I, sites were screened and identified. Then in Phase II, potential sites were evaluated according to three restrictive criteria. The outcome of those first two phases was a final list of sites that satisfied the criteria identified by the EDB, DED and a literature review. Phase III described in this chapter, develops and explains a list of sixteen comprehensive criteria which will be used in Phase IV to rank the sites according to their relationships to each of the criteria. This chapter will describe each of the sixteen criteria in five main groups. The five groups include, location factors, utilities, environmental factors, community constraints, and general construction constraints.

\section{Location Factors}

The first group of criteria consists of location factors associated with the distance to the nearest interchange and the possibility of rail access. Access to transportation was the most important location factor identified by Schmenner(1982) and the second most important location factor identified by Stafford(1985). The literature also suggests that the most attractive development sites are those within three miles of a direct access to a major regional or interstate highway. Rail access is seen as a unique site attribute in that it is considered to be a valuable asset, but is significant to a fairly narrow group of potential industrial occupants of a site. In some respects, rail access is used to categorize the sites' future use rather than to 
establish its marketability or development potential. In this study, rail access was determined from interviews with staff members of the Rhode Island Department of Transportation

\section{Infrastructure}

The second evaluation criteria is the town's infrastructure system. This criteria includes public sewer and water pipelines and access to electric power or gas lines. The distance between each sites and the nearest utility access points will be measured.

\section{Environmental Factors}

The third evaluation criteria includes environmental factors such as soils, wetlands, flood plains, steep slopes and ISDS capacity. Soil types are important to locate and classify, because of the limitations different soils can have on development. These limiting factors include such factors as bearing capacity, drainage, wetness and ISDS capacity.

Wetlands are an important factor, because of the substantial restrictions placed on development by state agencies such as the Department of Environmental Management and federal agencies such as the Environmental Protection Agency. These agencies restrict any attempts to alter wetlands in ways that would destroy the wetlands environmental value in exchange for developmental values. In this phase, wetlands are mapped through soils and geology mapping, 
which are methods used to identify flat or steep topography, poor drainage areas, permanent or temporary soil saturation and standing water.

Flood Plains are the last environmental factor examined in this subgroup. Flood plains were identified through the use of Federal Environmental Management Agency (FEMA) flood insurance maps. These maps categories topography with a rating system from $A$ to $D$, which indicates the likelihood of an area becoming flooded in a 100 year rain storm. As the rating moves from $A$ to $D$, the likelihood of flooding in that area decreases.

The last environmental constraint is topography. The topography of each site was examined to locate areas with a slope greater than $15 \%$ and areas with a slope of less than $2 \%$. These areas indicate a need for special designs to be used so that run-off and erosion will not become a problem. In areas with slopes greater than $15 \%$, newly cleared parcels of land will have an increase in run-off and soil erosion unless a proper method of clearing the site is used and silt fences or hay bails are used to prevent soil erosion. In area with slopes less than $2 \%$, run-off pools in area of the site, instead of draining into streams or detention ponds. To avoid such problems, sites have to be designed to include channels and manmade drainage systems that will eliminate pooling and drainage problems. 


\section{Community Constraints}

The fourth evaluation criteria includes the cultural resources of an area. This criteria is used as an indicator for impacts on sensitive land uses around the site such as community facilities, adjacent land uses such as residential and commercial zones and historical or archaeological sites. The first two uses were measured by their distance from the site and the length in linear feet by which the site bounds residential or commercial uses. The last two uses, potential and identified historical and archaeological sites, were identified by town maps and interviews with staff members at the Rhode Island Historical Preservation Commission.

\section{General Building Constraints}

The final evaluation criteria includes developmental constraints, such as existing zoning and the number of owners. Existing zoning and the number of owners per site were recorded for each site through the use of Westerly's 1992 Comprehensive Plan and from the Town's Tax Assessor's office. Existing zoning was evaluated to determine whether zoning changes would be necessary to allow industrial uses. The number of owners in a potential site were identified to determine the number of participants that would be involved in the creation of one large single site.

Each of the sites were rendered in Figures $3.1-3.5$ to allow for an approximation of their size and shape. Other site specific 
characteristics such as site perimeter, property boundaries, open water and streams, hydric soils and steep slopes were identified with their general location. The sixteen criteria listed and explained in this chapter will be tabulated and compared in the following chapter. 

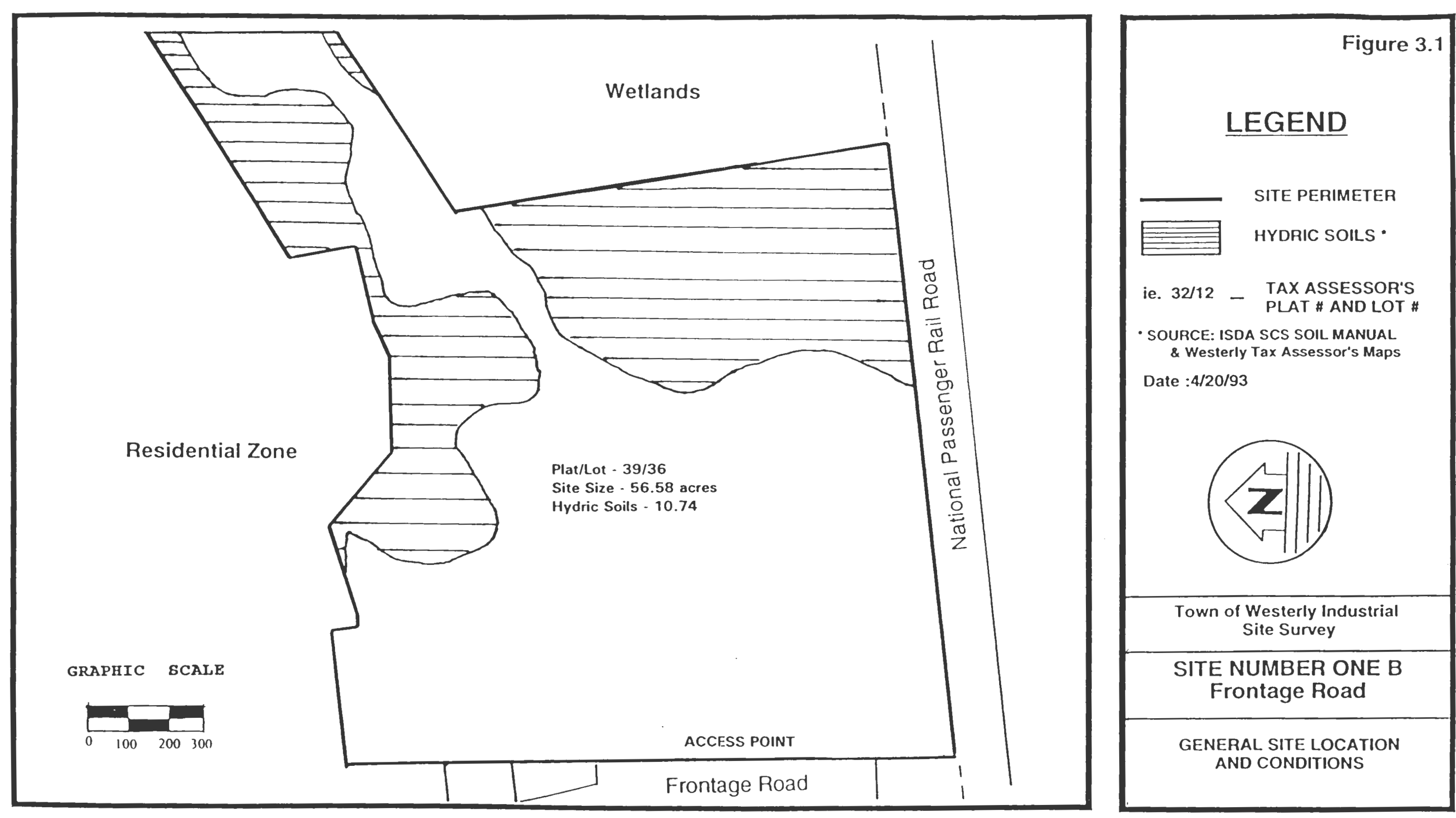

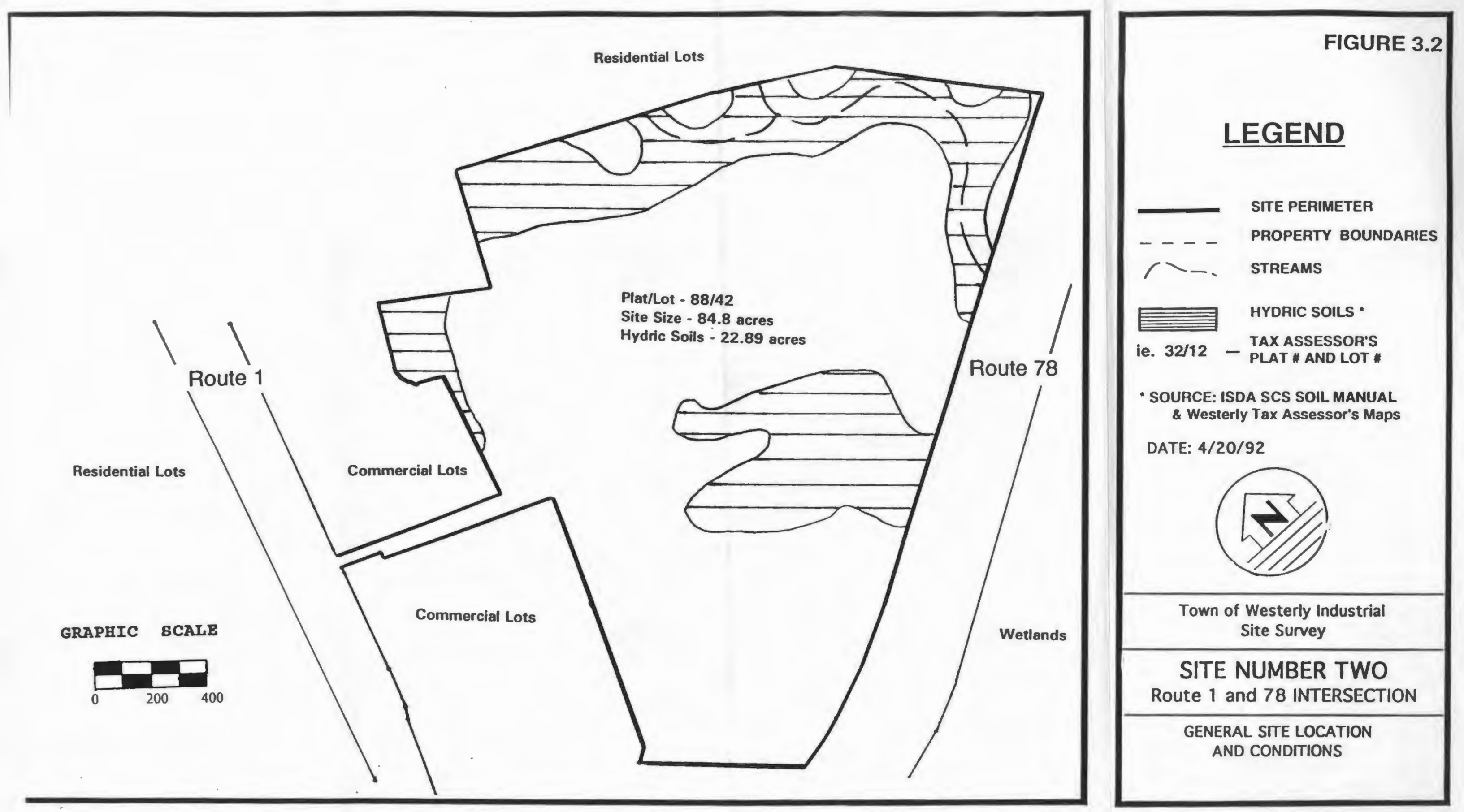

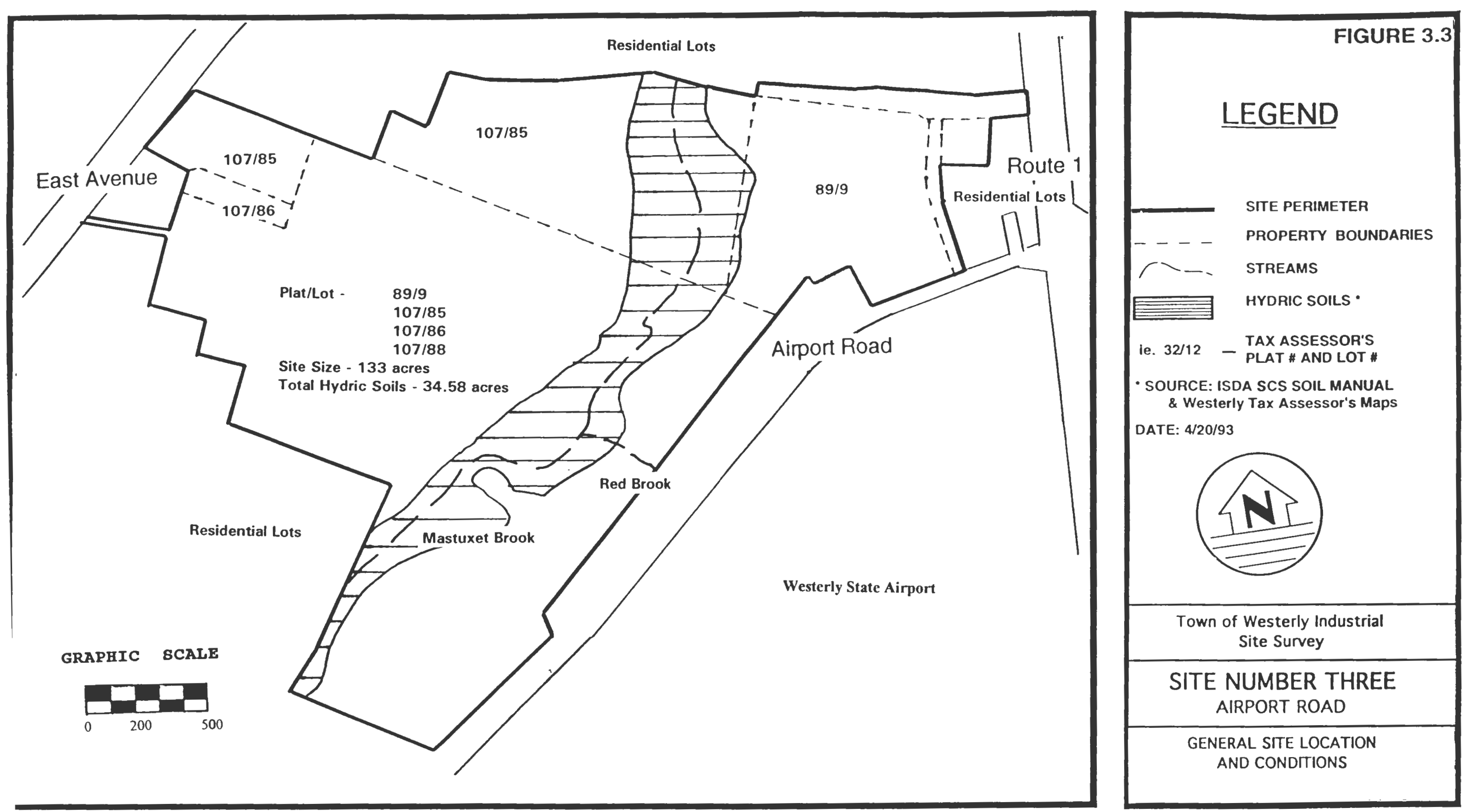

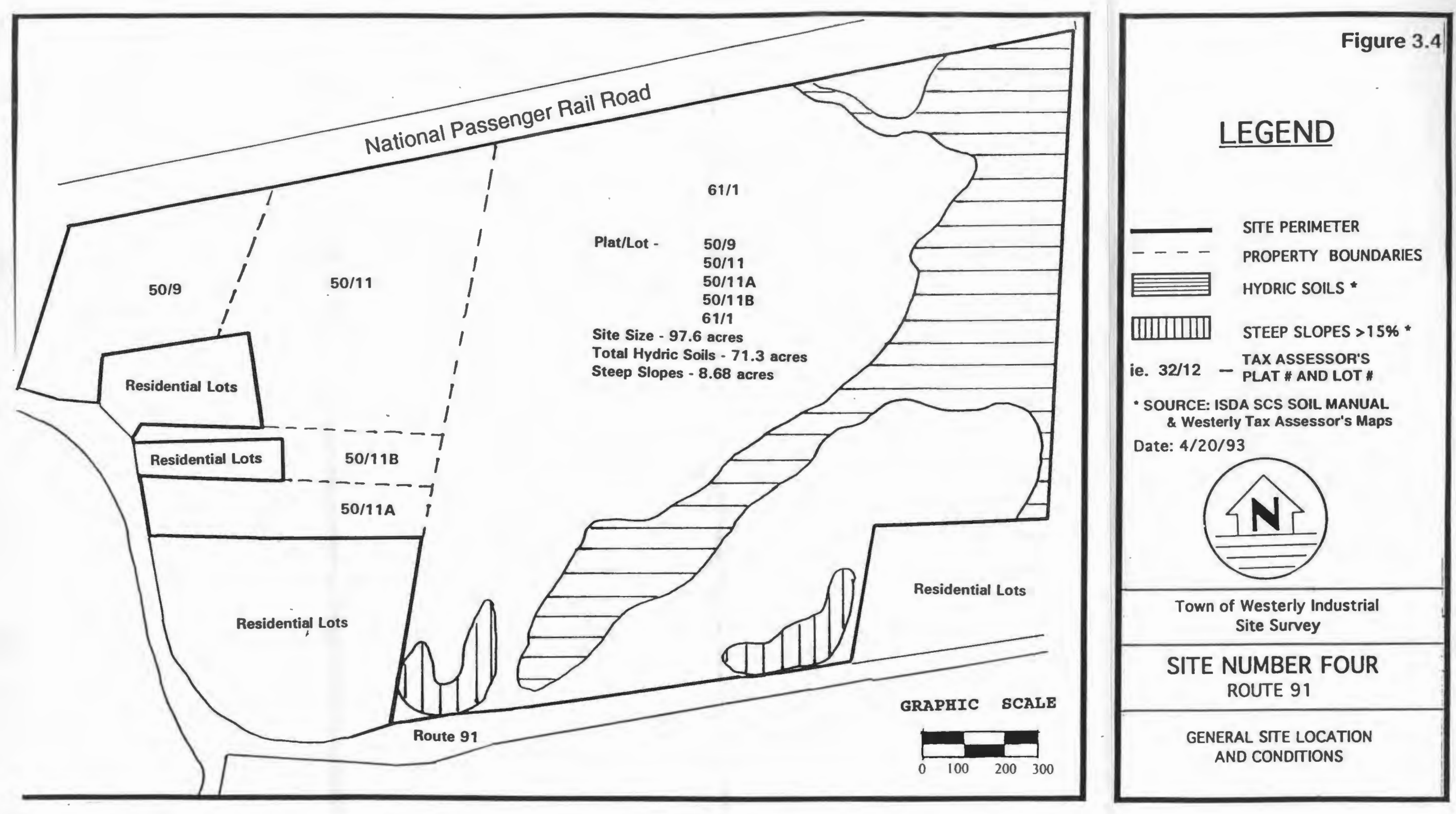

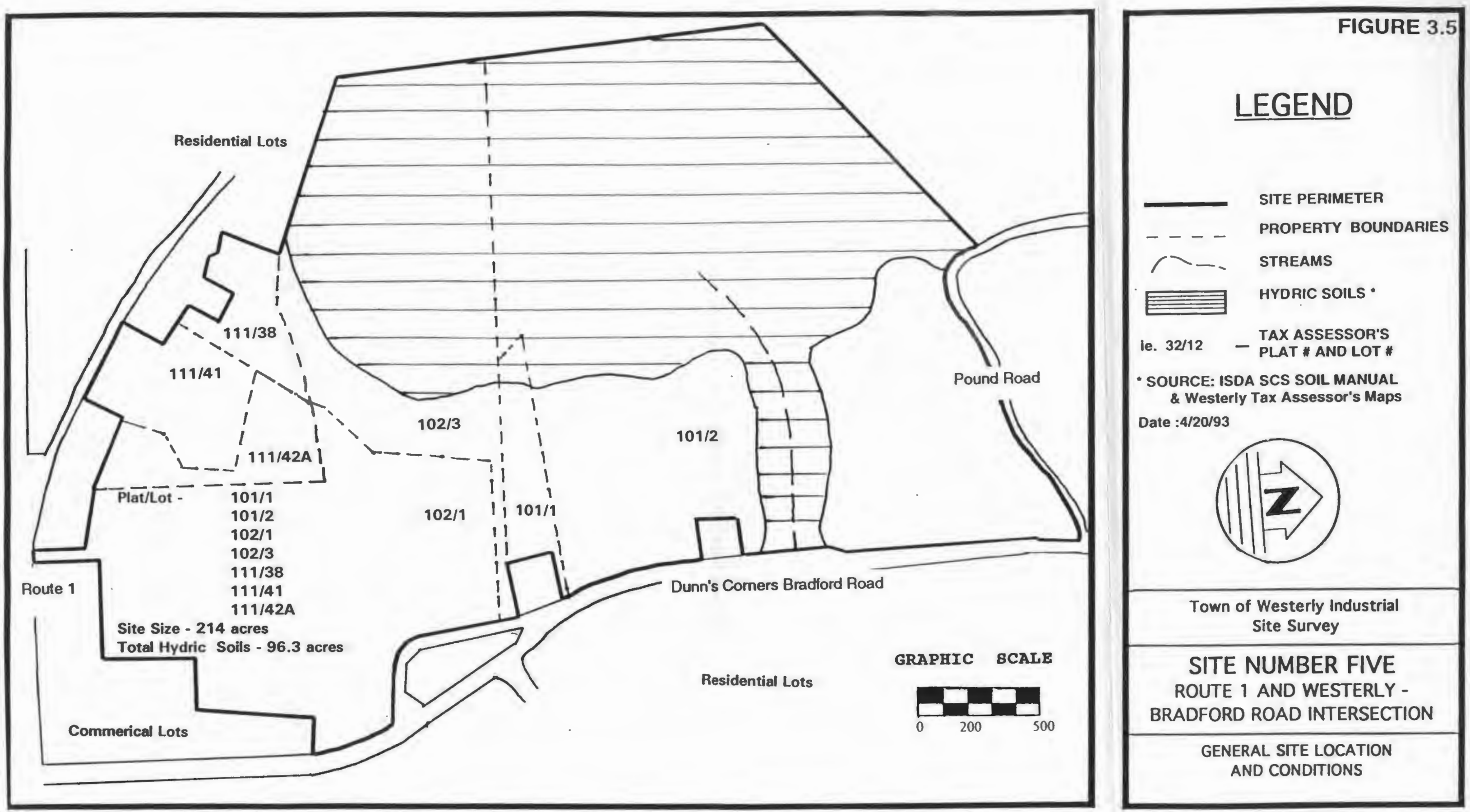


\section{FINAL SITE EVALUATION AND SELECTION}

The final phase of this report will use the sixteen criteria, which are developed and explained in chapter three to evaluate the potential for the economic development use of each site. The results are expressed in specific quantitative measures in Table 4.1 for each of the criteria. The five criteria groups used in this final assessment are location, infrastructure, environmental constraints, community constraints and general development constraints. Each of the evaluative criteria and their units of measure are described as follows:

\section{Location factors}

Location factors such as access to highways will be measured by the distance between the sites and facilities in miles. Access to rail services is indicated as $\mathrm{Y}=$ existing or convenient or $\mathrm{N}=$ nonexistent or not readily accessible.

\section{Environmental factors}

Environmental factors will be measured by the percentage of the site that has steep slopes, wetlands, hydric soils, streams and ponds. A percentage of these factors compared to the size of the site will be calculated so that each site can be compared on a more equal basis without being penalized by the size of the site. 


\section{Community Constraints}

Community constraints include sensitive land uses around sites such as community facilities, residential and commercial zones and historical or archaeological sites. Linear feet will be the unit of measurement for an analysis of the length of shared boundary lines between sites and properties that have sensitive uses. A measuring technique for analyzing historical or archaeological sites was not necessary, because town maps and staff members of the Rhode Island Historical Preservation Commission revealed that the five sites were void of either type of sites.

\section{General Construction Constraints}

Development constraints include the number of owners that hold title to property needed to create large sites and the current zoning of sites. Therefore, the number of owners from each parcel in each individual site will be counted(See Appendix A). Zoning designations are also a constraint when trying to change to industrial use. The designations of each site will be given in the abbreviated form used on the Westerly Official Zoning Map and explained in a key after Table 4.1. 
Table 4.1 Site Evaluation by Sixteen Criteria(Measured Matrix)

\begin{tabular}{|c|c|c|c|c|c|}
\hline SITE DESIGNATION & $1 \mathrm{~B}$ & 2 & 3 & 4 & 5 \\
\hline \multicolumn{6}{|l|}{ LOCATION } \\
\hline ACCESS-DISTANCE TO NEAREST INTERCHANGE (MILES) & 0.25 & 0.25 & 0.05 & 1.17 & 0.1 \\
\hline RAIL ACCESS & $\mathrm{Y}$ & $\mathrm{N}$ & $\mathrm{N}$ & Y & $\mathrm{N}$ \\
\hline \multicolumn{6}{|l|}{ INFRASTRUCTURE } \\
\hline PUBUC WATER-NEAREST CONNECTION (MILES) & 0.10 & 0.18 & $\mathrm{RF}$ & 1.2 & $\mathrm{RF}$ \\
\hline SEWER-NEAREST CONNECTION (MILES) & .25 & .18 & $\mathrm{RF}$ & 1.2 & 2.17 \\
\hline \multicolumn{6}{|l|}{ ENVIRONMENTAL } \\
\hline AQUIFER-RECHARGE AREA(\% OF SITE ACREAGE) & $100 \%$ & $0 \%$ & $0 \%$ & $100 \%$ & $97 \%$ \\
\hline PRIME AGRICULTURAL SOILS(\% OF SITE ACREAGE) & O\% & $73 \%$ & $49 \%$ & $56 \%$ & $20 \%$ \\
\hline WETLANDS AND HYDRIC SOILS ( $\%$ OF SITE ACREAGE) & $19 \%$ & $27 \%$ & $26 \%$ & $18 \%$ & $45 \%$ \\
\hline STEEP SLOPES-GREATER > $15 \%(\%$ OF SITE ACREAGE) & $1 \%$ & $0 \%$ & $0 \%$ & $8.9 \%$ & $0 \%$ \\
\hline SURFACE WATER-PONDS ( $\%$ OF SITE ACREAGE) & $0 \%$ & $0 \%$ & $0 \%$ & $0 \%$ & $0 \%$ \\
\hline SURFACE WATER-STREAMS (MILES) & 0 & .38 & .57 & 0 & 0 \\
\hline \multicolumn{6}{|l|}{ COMMUNITY CONSTRAINTS } \\
\hline ADJACENT RESIDENTLAL-LINEAR IMPACT (FEET) & 1,870 & 2,050 & 6,725 & 4664 & 6,555 \\
\hline HISTORICAL ARCHEOLOGICAL (SITES AFFECTED) & 0 & 0 & 0 & 0 & 0 \\
\hline \multicolumn{6}{|l|}{ GENERAL BUILDING CONTRAINTS } \\
\hline CURRENT ZONING & MI & B2 & Spec $^{*}$ & $\mathrm{MI}$ & A I \\
\hline NUMBER OF PROPERTY OWNERS & 1 & 1 & 4 & 5 & 6 \\
\hline SITE SIZE-ACRES & 56.58 & 84.8 & 133 & 97.6 & 214 \\
\hline DEVELOPABLE ARCES & 42.26 & 61.9 & 98.4 & 71.3 & 114.4 \\
\hline
\end{tabular}

Key: Zoning Designations

MI- Manufacturing B2 - Business related uses Al - Agricultural Uses

RF - Road Frontage $\quad \mathrm{Y}=$ rail access available $\quad \mathrm{N}$ = rail access not available Spec $^{\star}$ - Special Use District (Westerly 1992 Comprehensive Plan) 


\section{Final Site Evaluation}

Table 4.1 presents the results from evaluating each site by the sixteen criteria developed in chapter three and by using the units of measurement described in the first section of this chapter. From this data, it is possible to arrange the sites in a weighted matrix from Best (first) to Worst (fifth) according to each sites specific characteristics in each of the criteria. Using this method, the conditions of each site relative to each criteria are shown in Table 4.2. Table 4.2 performs two functions. The table functions as a means of providing the ability to identify criteria or a set of criteria felt to be the most important and also shows which sites ranked the best in those criteria. The other function of Table 4.2 is to provide a means for an overall ranking of the sites with all sixteen of the criteria taken into account.

Evaluating the sites by the number of times they were ranked first, second, third, fourth or fifth in each of the criteria allows an overall ranking to be calculated. The evaluation reveals that site three would be considered the best site out of the five, because it was ranked first, second and third a total of eleven times and ranked fourth and fifth only twice.

Site One B would be ranked second overall, because it ranked first, second and third ten times, while ranking fourth and fifth five times. The same calculations were performed for the remaining sites and 
Table 4.2 Sites Ranking per Criteria

\begin{tabular}{|c|c|c|c|c|c|}
\hline COMPARISON BY INDIVIDUAL CRITERIA & \begin{tabular}{|l} 
BEST \\
FIRST \\
\end{tabular} & $\begin{array}{l}<<--- \\
\text { SECOND }\end{array}$ & THIRD & $\begin{array}{l}-\cdots>> \\
\text { FOURTH }\end{array}$ & $\begin{array}{l}\text { WORST } \\
\text { FIFTH }\end{array}$ \\
\hline \multicolumn{6}{|l|}{ LOCATIONAL FACTORS } \\
\hline ACCESS-DISTANCE TO NEAREST INTERCHANGE (MILES) & 3 & 5 & $1 \mathrm{~B}$ & 2 & 4 \\
\hline RAIL ACCESS & $1 \mathrm{~B}$ & 5 & & & \\
\hline \multicolumn{6}{|l|}{ INFRASTRUCTURE } \\
\hline PUBLIC WATER-NEAREST CONNECTION (MILES) & 3 & 5 & $1 \mathrm{~B}$ & 2 & 4 \\
\hline SEWER-NEAREST CONNECTION (MILES) & 3 & 2 & $1 \mathrm{~B}$ & 4 & 5 \\
\hline \multicolumn{6}{|l|}{ ENVIRONMENTAL } \\
\hline AQUIFER-RECHARGE AREA( $\%$ OF SITE ACREAGE) & 2 & 3 & 5 & 1B & 4 \\
\hline PRIME AGRICULTURAL SOILS( $\%$ OF SITE ACREAGE) & $1 \mathrm{~B}$ & 5 & 3 & 4 & 2 \\
\hline WETLANDS AND HYDRIC SOILS (\% OF SITE ACREAGE) & 4 & $1 \mathrm{~B}$ & 3 & 2 & 5 \\
\hline STEEP SLOPES-GREATER $>15 \%$ ( $\%$ OF SITE ACREAGE) & 2 & 3 & 5 & $1 \mathrm{~B}$ & 4 \\
\hline SURFACE WATER-PONDS ( $\%$ OF SITE ACREAGE) & $--\cdot$ & $\cdots$ & --- & --- & --- \\
\hline SURFACE WATER-STREAMS (MILES) & $1 \mathrm{~B}$ & 4 & 5 & 2 & 3 \\
\hline \multicolumn{6}{|l|}{ COMMUNITY CONSTRAINTS } \\
\hline ADJACENT RESIDENTLAL-LINEAR IMPACT (FEET) & $1 \mathrm{~B}$ & 2 & 4 & 5 & 3 \\
\hline HISTORICAL ARCHEOLOGICAL (SITES AFFECTED) & --- & --- & --- & $--\cdot$ & --- \\
\hline \multicolumn{6}{|l|}{ GENERAL BUILDING CONTRAINTS } \\
\hline CURRENT ZONING & $1 \mathrm{~B}$ & 4 & 3 & 2 & 5 \\
\hline NUMBER OF PROPERTY OWNERS & $1 \mathrm{~B}$ & 2 & 3 & 4 & 5 \\
\hline SITE SIZE-ACRES & 5 & 3 & 4 & 2 & $1 \mathrm{~B}$ \\
\hline DEVELOPABLE ARCES & 5 & 3 & 4 & 2 & $1 \mathrm{~B}$ \\
\hline
\end{tabular}

Key: 1B - Site 1B, Frontage Road 2 - Site Two, Route 1 and Route 78

3 - Site Three, Airport Road 4 - Site Four, Route 91

5 - Site 5, Route 1 and Westerly-Bradford Road 
revealed that their ranking was as follows: Site Five ranked third, Site Four ranked fourth and Site Two ranked last.

From the data calculated in Table 4.1, ranges in the units of measurement for each criteria could be calculated, so that an impact rating of High, Medium and Low could then be assigned to each site per criteria in Table 4.3. The total number of each impact rating for individual sites will then be used for a basis of comparison between sites. For example, a site without high impact ratings will be ranked better overall than a site with two or three high impact ratings. A comparison of each sites combined ratings can be conducted to identify which site is the best out of the list to be considered for industrial development. The sites will be ranked by this assessment approach and tabulated in Table 4.4. Included in Table 4.4 is a list of the advantages and disadvantages of each site, so that readers of this report will beable to decide there own ranking for the sites. The following narrative explains the tabulated results in Table 4.4 in further detail.

Two criteria used in the evaluation of each of the sites will not be mentioned in the following narrative, because all of the sites achieved the same results in those measurement criteria. The criteria are, surface water-ponds as a percentage of the sites acreage and effects on historical and archaeological sites. These two criteria were eliminated because they were not present within the boundary lines of any of the sites. These facts were verified from the Soil 
Table 4.3 Site analysis using ranges of units of measure

\begin{tabular}{|c|c|c|c|c|c|}
\hline SITE DESIGNATION & $1 \mathrm{~B}$ & 2 & 3 & 4 & 5 \\
\hline \multicolumn{6}{|l|}{ LOCATION } \\
\hline ACCESS-DISTANCE TO NEAREST INTERCHANGE (MILES) & Mod & Mod & Low & High & Mod \\
\hline RAIL ACCESS & Y & $\mathrm{N}$ & $\mathrm{N}$ & $\mathrm{N}$ & $\mathrm{Y}$ \\
\hline \multicolumn{6}{|l|}{ INFRASTRUCTURE } \\
\hline PUBLIC WATER-NEAREST CONNECTION (MILES) & Mod & High & Low & Mod & Low \\
\hline SEWER-NEAREST CONNECTION (MILES) & Mod & Mod & Low & High & High \\
\hline \multicolumn{6}{|l|}{ ENVIRONMENTAL } \\
\hline AQUIFER-RECHARGE AREA( $\%$ OF SITE ACREAGE) & High & Low & Low & High & High \\
\hline PRIME AGRICULTURAL SOILS( $\%$ OF SITE ACREAGE) & Low & High & Mod & High & Low \\
\hline WETLANDS AND HYDRIC SOILS ( $\%$ OF SITE ACREAGE) & Low & Mod & Mod & Low & High \\
\hline STEEP SLOPES-GREATER > $15 \%$ ( $\%$ OF SITE ACREAGE) & Low & Low & Low & High & Low \\
\hline SURFACE WATER-PONDS ( $\%$ OF SITE ACREAGE) & Low & Low & Low & Low & Low \\
\hline SURFACE WATER-STREAMS (MILES) & Low & Mod & High & Low & Low \\
\hline \multicolumn{6}{|l|}{ COMMUNITY CONSTRAINTS } \\
\hline ADJACENT RESIDENTIAL-LINEAR IMPACT (FEET) & Low & Mod & High & Mod & High \\
\hline HISTORICAL ARCHEOLOGICAL (SITES AFFECTED) & Low & Low & Low & Low & Low \\
\hline \multicolumn{6}{|l|}{ GENERAL BUILDING CONTRAINTS } \\
\hline CURRENT ZONING & Low & Mod & Low & Low & Mod \\
\hline NUMBER OF PROPERTY OWNERS & Low & Low & Mod & High & High \\
\hline SITE SIZE-ACRES & High & Mod & Low & Mod & Low \\
\hline DEVLOPABLE ACRES & High & Mod & Low & Mod & Low \\
\hline
\end{tabular}

Key: $\quad$ High - high impacts on criteria

Moderate - moderate impacts on criteria

Low - low impacts on criteria 
Table 4.4 Summary Table

\begin{tabular}{|c|c|c|c|c|c|c|c|}
\hline $\begin{array}{l}\text { SITE } \\
\text { NUMBER }\end{array}$ & $\begin{array}{l}\text { LOCATIONAL } \\
\text { CONSTRAINTS }\end{array}$ & $\begin{array}{l}\text { INFRASTRUCTURE } \\
\text { CONSTRAINST }\end{array}$ & $\begin{array}{l}\text { ENVIRONMENTAL } \\
\text { CONSTRAINTS }\end{array}$ & $\begin{array}{l}\text { CULTURAL } \\
\text { CONSTRAINTS } \\
\end{array}$ & ADVANTAGES & DISADVANTAGES & $\begin{array}{l}\text { SITE RANK - } \\
\text { DEVEL ACRES }\end{array}$ \\
\hline 18 & $\begin{array}{l}\text { Average discance to } \\
\text { nearest highway } \\
\text { interchange. Rail } \\
\text { senice avaliable }\end{array}$ & $\begin{array}{l}\text { Average distance to } \\
\text { public water and } \\
\text { sewer connections }\end{array}$ & $\begin{array}{l}\text { Higher than average } \\
\text { percentage of acreage in } \\
\text { aquifer-recharge area. } \\
\text { Lower than average on all } \\
\text { other envronmental } \\
\text { constralnsts. }\end{array}$ & $\begin{array}{l}\text { Lower than average } \\
\text { on both adjacent } \\
\text { residentail zones } \\
\text { and historical and } \\
\text { archaeological sites }\end{array}$ & $\begin{array}{l}\text { - Rall access } \\
\text { - Low impacts on } \\
\text { most environmental } \\
\text { factors. } \\
\text { - Good visability } \\
\text { from Rt. } 78 \\
\end{array}$ & $\begin{array}{l}\text { - Over Westerly's } \\
\text { main aquifer } \\
\text { recharge area }\end{array}$ & $\begin{array}{l}\text { Ranked } 2 \text { nd out of } 5 \\
+2.26 \text { developable } \\
\text { acres out of } 56.58\end{array}$ \\
\hline 2 & $\begin{array}{l}\text { Average distance to } \\
\text { nearest highway } \\
\text { interchange. Rail } \\
\text { service not avalable }\end{array}$ & $\begin{array}{l}\text { Longer than average } \\
\text { distance to water, } \\
\text { but average distance } \\
\text { to sewer connections }\end{array}$ & $\begin{array}{l}\text { Higher than average for the } \\
\text { percentage of site in } \\
\text { aquifer-recharge area and } \\
\text { prime farm lands. Average } \\
\text { impact on wetlands and } \\
\text { hydric solls. Lower than } \\
\text { average for percent of site } \\
\text { in an aquifer-recharge } \\
\text { area, with steep slopes and } \\
\text { ponds }\end{array}$ & $\begin{array}{l}\text { Average impact on } \\
\text { adjacent residential } \\
\text { zones. Below } \\
\text { average impact on } \\
\text { historical and } \\
\text { archaeological sites }\end{array}$ & $\begin{array}{l}\text { - Not over } \\
\text { Westerly's main } \\
\text { aquifer recharge } \\
\text { area } \\
\text { - Low number of } \\
\text { property owners } \\
\text { Good visabllity } \\
\text { from Rt. } 78\end{array}$ & $\begin{array}{l}\text { - No rail access } \\
\text { - Has a high } \\
\text { percentage of prime } \\
\text { agricultural land }\end{array}$ & $\begin{array}{l}\text { Ranked th out of } 5 \\
62 \text { developable } \\
\text { acres out of } 84.8\end{array}$ \\
\hline 3 & $\begin{array}{l}\text { Below average } \\
\text { distance to nearest } \\
\text { highway interchang. } \\
\text { Rail service not } \\
\text { available }\end{array}$ & $\begin{array}{l}\text { Shorter than average } \\
\text { distance form water } \\
\text { and sewer } \\
\text { connections }\end{array}$ & $\begin{array}{l}\text { Higher than average impact } \\
\text { for streams. Average Impaci } \\
\text { on the percencage of acreage } \\
\text { considered prime farm land. } \\
\text { and wetland or hyd nc solts. } \\
\text { Lower than average for } \\
\text { aquirfer recharge areas, steep } \\
\text { slopes and ponds }\end{array}$ & $\begin{array}{l}\text { Higher than average } \\
\text { Impact on adjacent } \\
\text { residential zones. } \\
\text { Below average } \\
\text { impact on } \\
\text { historical and } \\
\text { archaeological sites } \\
\end{array}$ & $\begin{array}{l}\text { - Large sire } \\
\text { - Great access to } \\
\text { highways and } \\
\text { utilities } \\
\text { - Not over } \\
\text { Westerly's aquifer } \\
\text { recharge area } \\
\end{array}$ & $\begin{array}{l}\text { - No rail access } \\
\text { - Two streams } \\
\text { transect site }\end{array}$ & $\begin{array}{l}\text { Ranked Ist out of } 5 \\
98+t \text { developable } \\
\text { acres out of } 133\end{array}$ \\
\hline 4 & $\begin{array}{l}\text { Higher than average } \\
\text { distance to nearesi } \\
\text { highway } \\
\text { interchange. Rail } \\
\text { service aavailable }\end{array}$ & $\begin{array}{l}\text { Average distance to } \\
\text { public water } \\
\text { connections, but } \\
\text { longer than average } \\
\text { distrance for sewers }\end{array}$ & $\begin{array}{l}\text { Higher than average impaci on } \\
\text { aquiler-recharge areas, steep } \\
\text { slopes and prime farmland. } \\
\text { No average impacts. Lower } \\
\text { than average impacis on } \\
\text { wedasds and hydric solls, } \\
\text { ponds and streams. }\end{array}$ & $\begin{array}{l}\text { Average impacion } \\
\text { adjacent residential } \\
\text { zones. Below } \\
\text { average impact on } \\
\text { historical and } \\
\text { archaeological sites }\end{array}$ & $\begin{array}{l}\text { - Low impact on } \\
\text { wetlands, hydric } \\
\text { solls, ponds and } \\
\text { streams } \\
\text { - Access to rail } \\
\end{array}$ & $\begin{array}{l}\text { - No public water } \\
\text { or sewers } \\
\text { - Site is in } \\
\text { Westerly's acquifer } \\
\text { recharge area }\end{array}$ & $\begin{array}{l}\text { Ranked } 5 \text { th out of } \\
71.3 \text { developable } \\
\text { acres out of } 97.6\end{array}$ \\
\hline 5 & $\begin{array}{l}\text { Average distance } \\
\text { form highway } \\
\text { interchange. Rail } \\
\text { service not available }\end{array}$ & $\begin{array}{l}\text { Shorter than average } \\
\text { distance form water } \\
\text { connections, but } \\
\text { longer than average } \\
\text { distance to sewer } \\
\text { connectlons }\end{array}$ & $\begin{array}{l}\text { Higher than average } \\
\text { Impacts on aquifer- } \\
\text { recharge areas and } \\
\text { wetlands and hydric solls. } \\
\text { No average impacts. Lower } \\
\text { than average impacts on } \\
\text { farmland, steep slopes and } \\
\text { streams. }\end{array}$ & $\begin{array}{l}\text { Higher than average } \\
\text { Impact on adjacent } \\
\text { residential zones. } \\
\text { Below average } \\
\text { Impact on } \\
\text { hlstorical and } \\
\text { archaeological sites }\end{array}$ & $\begin{array}{l}\text { - Largest site and } \\
\text { developable area }\end{array}$ & $\begin{array}{l}\text { - No rall access } \\
\text { - No access to } \\
\text { sewers } \\
\text { - Poor visability } \\
\text { - Site is in } \\
\text { Westerly's major } \\
\text { Acquifer recharge } \\
\text { area }\end{array}$ & $\begin{array}{l}\text { Ranked } 3 \text { rod out of } 5 \\
11+\text { developable } \\
\text { acres out of } 214\end{array}$ \\
\hline
\end{tabular}


Conservation Manual and interviews with the Rhode Island Historical Preservation Commission.

\section{Final Site Ranking}

Site Three is ranked first out of the five sites. This site has one of the fewest High impacts, the fewest combined High and Moderate impacts and the most Low impacts. The site was ranked High in two criteria, Moderate in three criteria and Low in ten criteria. The site was ranked High in miles of streams and linear feet of adjacent residential zones. The site ranked Moderately in the percentage of the site considered prime agricultural land, wetlands or hydric soils and in the number of property owners holding rights to property need for the creation a large site in that area.

Although Site Three does not have access to rail service, it did rank Low in criteria such as the distance to the nearest interchange and public utilities connection point. The site also had Low constraints due to overall site size and the number developable acres of the site after constraints were subtracted. It should also be noted that Site Three is the second of the two sites out of the list of sites that is not within Westerly's major aquifer recharge area.

Site $1 B$ is ranked second out of the five sites. The site was ranked High in three criteria, Moderate in three criteria and Low in nine criteria. The sites ranked High in the percentage of the site that was 
in an aquifer recharge area and had the lowest overall site size and developable number of acres. The site was also ranked as Moderate for the distance to the nearest highway interchange and for the distances from both water and sewers services.

The sites advantages include access to the National Railroad Passenger Corridor and nine criteria which are considered to be Low impacts. The Low impacts were in criteria which include the percentage of the site considered prime farmland, wetlands or hydric soils, steep sloped, or parts of the site adjacent to residential zones. The site also ranked Low in the criteria concerning current zoning and the number of property owners.

Site Five was ranked third out of the five sites. The site was ranked High in five criteria, Moderate in two criteria and Low in eight criteria. The sites ranked High in criteria such as the distance from the site to the nearest sewer connection point, the percentage of the site that is in an aquifer recharge area or is wetland and hydric soils. Other criteria that this site ranked High in are the length of common boundary lines with adjacent residential uses, and the number of property owners that hold title to property needed to create large sites.

The site had two Moderate impacts related to the distance from the site to the nearest interchange and needed zoning changes. In addition to rail access, the sites Low impacts included the distance from public sewers, the percentage of the site that had steep slopes, 
and the impact on streams. Other Low impacts included site size and the amount of developable acres. It should be noted that this site is the largest of all five and has the most developable number of acres.

Site Two ranked fourth out of the five sites. This site had two criteria ranked as High impacts, eight criteria ranked as Moderate impacts and five criteria ranked as Low. Site two ranked High in criteria such as distance to the nearest public water source and the percentage of the site that was considered prime agriculture land.

The eight Moderately ranked impacts in Site Two, include the distance to the towns' public sewer system and nearest highway interchange, length of streams, the percentage of the site which are wetlands or hydric soils and the length of the site adjacent to residential zones. Site Two also ranked Moderately in the criteria of site size and developable acres.

Lower ranked criteria for Site Two include the percentage of the site which is in an aquifer recharge area, on steep slopes, and the number of owners that hold title to parcels needed to create large sites. It should be noted that Site Two is one of two out of the list of sites that is not within Westerly's major aquifer recharge area.

Site Four is ranked last out of the five sites. The site was ranked High in six criteria, Moderate in four criteria and Low in five criteria. The site ranked as a High impact in criteria concerned with the distance to the nearest highway interchange, public sewer system 
connection and in the number of property owners. The other three criteria which ranked High are, the distance from the site to the nearest highway interchange, the percentage of the site which is within an aquifer-recharge area and acres with slopes greater than 15 percent.

The site had four criteria which were ranked as Moderate impacts. These criteria include, the distance to the nearest connection for public water service and the length in linear feet of common boundary lines with adjacent residential zones. Finally, site size and the number of developable acres were also rank as Moderate.

Site Four had five Low impact ratings that make up the sites advantages. The site has Low impacts on environmental factors such as wetlands and hydric soils, ponds and streams. The site also has a Low impact on zoning and historical and archaeological sites. 


\section{Conclusion and Recommendations}

This study has developed and applied a site analysis process in order to identify the most suitable sites in the Town of Westerly for industrial uses. The study incorporated the "Blue Ribbon Approach" and the "Comprehensive Planning Approach" inorder to develop evaluative criteria. Progressively restrictive and detailed criteria were applied to an initial list of ten potential sites. Of the ten sites, three satisfied all the basic criteria, however two other sites were allowed to remain, because their total acreage was significant enough to warrant consideration.

The remaining sites of the orignial ten, were then evaluated by sixteen criteria which were designed to allow each site to be compared by individual criteria and on an overall basis. The sixteen criteria were explained in detail, the findings from their apllication were shown in Tables 4.1 through 4.4. The results of the comparison revealed that Site Three, on Airport Road, had the most advantages of all the sites and the fewest combination of High and Moderate impacts. The ranks of the other sites can be reviewed in Table 4.4. 


\section{Recommendations}

Westerly's manufacturing problems are the results of a twelve year downward employment trend accentuated by the potential loss of the Towns' largest single employer, General Dynamics in Groton/New London, Connecticut This study answered one of the many questions which Westerly will have to address if they are to economically weather the 1990's and the twenty-first century. The question this study has answered is one of location; where are the potential industrial sites in Westerly and of those sites, which is the most suitable for development once evaluated by a set of basic criteria.

The findings of this assessment provided a basis for strategic recommendations which will improve Westerly's economic stability. In order to assure this goal, the single most pressing fact observed during this study must be met. The fact is, one or two full-time positions should to be created to generate the substantial effort required to create and implement an economic development plan which will efficiently, consistantly and persistantly assist Westerly in obtaining its' share of regional economic growth. Such positions should be filled by an economic development planner or an economic development specialist, which would be responsible for the duties associated with the following two sets of recommendations. These recommendations are structured to provide a serious effort to obtain a stable economic base. 
The recommendations that follow are separated into two sections. The first section gives recommendations pertaining to the facilitation of developing an industrial park. The second set of recommendations will pertain to other issues within the Town that need to be addressed simultaneously with the issue of manufacturing employment, if the Town is to successfully achieve its' goals of a stable economic base.

\section{Recommendations Related to Industrial Park Development}

1) The economic development planner should consider the five industrial sites identified in this study as locations with a high potential for supporting economic development and mention them in the Comprehensive Plan

A study by the Office of State Planning (Industrial Land Use Plan, May 1990) concluded that the State of Rhode Island is 10,000 construction-ready acres short of its goal of 24,000 acres. Since the zoning ordinance will be the primary mechanism for designating and reserving industrial land, Westerly should consider the results of this study in its' zoning evaluation. Areas identified in this study as having the potential for supporting industrial development should be given prime consideration for industrial zoning in the revision of the zoning ordinance as a result of the new Comprehensive Plan.

2) The economic development planner should further examine the industrial development feasibility of these sites. This would include 
a study of industrial space in the Southern New England Region to determine the supply of industrial sites versus the demand for sites. The study would also include a comparison between the advantages and disadvantages of Westerly's prime sites with sites in other cities and towns.

3) The economic development planner should have the list of sites acknowledged in the Town's Comprehensive Plan. Currently, Westerly does not have such a list, instead it has industrial zones that were designated before environmental factors were addressed with planning efforts. The economic development planner should also develop an industrial data base on these sites with industrial potential, so that improvements to the sites can be planned and so they can be protected for future use.

4) The economic development planner should rezone the individual sites for industrial uses so that competing residential and commercial uses will not eliminate the few industrial sites available. Currently, three of the five sites identified by this study are not zoned for industrial uses. This raised the possibility that one of more of the sites could be eliminated for future development if the appropriate zoning is not enacted.

5) The economic development planner should create a time table for capital improvement to increase the industrial potential of the sites by way of improving access to public utilities, road and intersection improvements. 
In order for the industrial sites to adequately provide for industrial development, they must be serviced by the proper utilities. This would help industrial recruiting efforts, because fully serviced industrial sites are generally given primary consideration by industrial firms seeking a new location. Therefore, when preparing plans for water and sewer expansion, the town should give priority to those improvements which service the designated industrial areas.

6) The economic development planner, in an effort to further facilitate industrial development, should consider replacing the zoning tables of prohibited and allowed uses with performance standards. Industrial performance standards would eliminate the need for the use list by providing quantifiable limits to allowable industrial development.

The primary advantage to this technique is that it allows the zoning ordinance to keep pace with current advances in manufacturing technology while at the same time maintaining the quality of the local environment. Furthermore, this technique eliminates the need to use such vague references to "obnoxious" or "nuisance " in the text of the ordinance. Different performance standards can be utilized for different districts (such as stringent standards for heavy industrial areas and lesser requirements for light industrial areas). Currently fourteen Rhode Island communities utilize some form of industrial performance standards (Industrial Zoning Guidelines, Office of State Planning 1980) 
7) The economic development planner should create an industrial Site Plan and Design Review process as part of their revision to the Zoning Ordinance. In order to ensure proper design and development of industrial parks, the Town should have the opportunity to evaluate industrial park projects on an individual basis. The Industrial Site Plan and Design Review Process would provide a mechanism for individual project review. The process can ensure that issues relating to traffic, the natural environment and adjacent land uses are adequately considered and resolved.

8) The economic development planner should identify growth industries that are compatible with Westerly's labor force. This analysis would focus recruiting efforts and identify potential needs for the creation of retraining programs.

9) The economic development planner should have the sites surveyed in more detail with engineering crews to determine the following: the exact edges of wetlands, areas with steep slopes, the acreage restricted in each site by 50 foot buffer strips around streams and the amount of land left for development after standard setback requirements are accounted for. The sites should also be examined for hazardous materials, because the cost and federally regulated procedures for handling such materials are extremely prohibitive. Therefore a complete examination for such materials should take place before a site is assembled. 
10) The economic development planner should develop a conceptual site plan with the layout of lots on the primary site identified by this study. This procedure will help determine the size and number of industries that can be recruited into the park.

11) The economic development planner should evaluate the number of industries that should be recruited into the park and a timetable for the recruitment effort should be created.

12) The economic development planner should work with Westerly's current planner to continue to develop a working relationship with neighboring towns so that a more regional planning effort can be created. Most of the towns and cities in Southern New England are planning the development of an industrial park in the hopes of offsetting employment loses. A potential means of gaining an advantage over these individual municipalities, may rest in a more regional approach which combines the efforts of several municipalities. A regional effort would have the financial and planning resources to address the issue of declining manufacturing employment with more success than a single town.

13) The economic development planner should consider applying for an Economic Development Administration (EDA) grant to develop an industrial park or for technical planning purposes. Given the recent downturn in the economy and the increase in unemployment, the State is eligible for EDA assistance. EDA has provided funding for 
many of the Rhode Island's industrial parks including South Ferry and Aquidneck in Middletown, and Blackstone Valley in Woonsocket.

14) The economic development planner should be prepared to involve the general public by initiating public workshops and meetings with concerned local groups at the beginning of the process. This will allow for public input and inform the public of events that might be relevant to them.

15) The economic development planner should also be responsible for contacting landowners within the primary site to initiate the process for an agreement or a compromise that will allow for the creation of the site.

\section{Recommendations for Other Issues}

It should be noted that the questions of where and how to increase manufacturing employment are only two of many major questions that the economic development planner needs to address, if Westerly is to effectively compete for its' share of regional economic growth. Some of the other issues that need to simultaneously be confronted are:

1) Vacant commercial space in the Downtown area

2) The Town's dependence on residential property taxes

3) Potential for growth in the economic sectors associated with the seasonal tourism industry 
4) Westerly's local economy in relationship to the Foxwood gambling casino expansion

1) The economic development planner should study a number of towns that have similar characteristics as Westerly and design a downtown revitalization program which will highlight the towns' historical and natural assets.

Throughout the United States, the downtown central business district in Westerly has experienced an increasing trend in commercial vacancy rates. Literature on the subject suggest that the lower cost of land, the ease in reaching commercial areas and the availability of abundant parking space are some of the most important reasons why commercial enterprises are moving to locations adjacent to arterial routes away from the traditional downtown area. In Westerly, retail commercial enterprises have moved from the downtown area to the sections of Route 1 called Granite Street and Franklin Street.

The very fact that chain retail stores are relocating to strip malls along Route 1, should not be taken as a negative occurrence which should be reversed. A similar approach should be taken as initiated in cities such as Ft. Collins and Boulder, Colorado which have used the absence of commonplace chain stores to accentuate the historical values present in the structures of their downtown areas.

2) The economic development planner should evaluate alternative measures that will enhance the Towns' tax base so that revenue for 
the Town will not be dependent on property values. As can be seen in Figure 5.1, in 1990, the Town of Westerly received $73.6 \%$ of its tax revenue from property tax. ${ }^{6}$ One such measure could be the development of special events, such as a town arts and crafts fair similar to the idea developed in Mystic Connecticut.

3) The economic development planner should explore ways in which the town can more effectively benefit from the existing summer season and also explore ways to lengthen the season. The issue of seasonality has been a long enduring characteristic of Westerly's because of the beach area and the short period of time during which the beach attracts tourist. As can be seen in Figure 5.2, there is a strong consistent pattern in the retail and service industries suggesting the dependence on an annual economic influence. That influence is the tourist industry which thrives in the five months between May and September.

One such approach might be the evaluation of the legal tools available for, and the feasibility of, reclaiming the property currently occupied by the Misquamicut State Beach. As the only State Beach in Rhode Island that consistently operates with a profit, ${ }^{7}$ the property would increase the Towns annual revenues and provide a suitable area for special summer events.

61991 Westerly Comprehensive Plan

7 Interview on July 25, 1992 with Staff members of the Rhode Island Planning Department 
Figure 5.1

TOTAL REVENUE \& MAJOR COMPONENTS

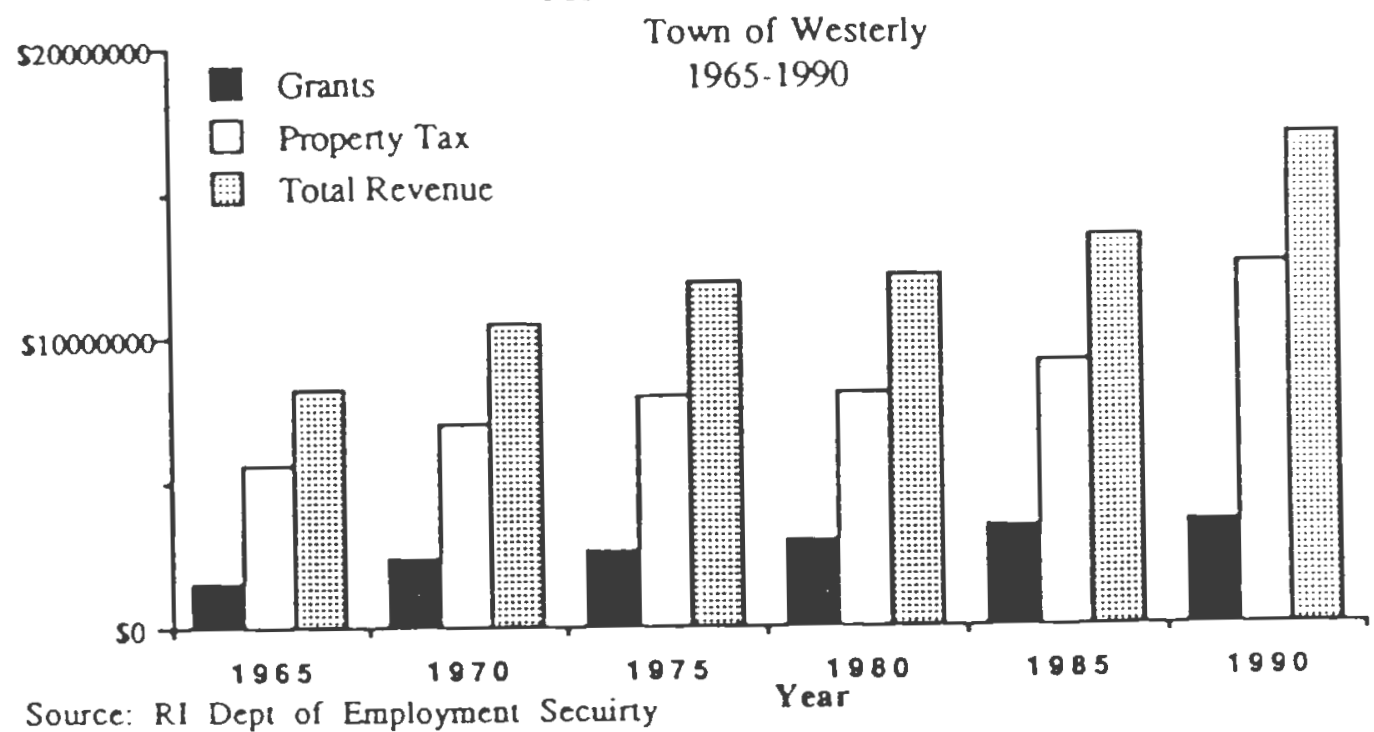

Figure 5.2

SEASONALTTY OF DOMTNANT SECTORS

Town of Westerly

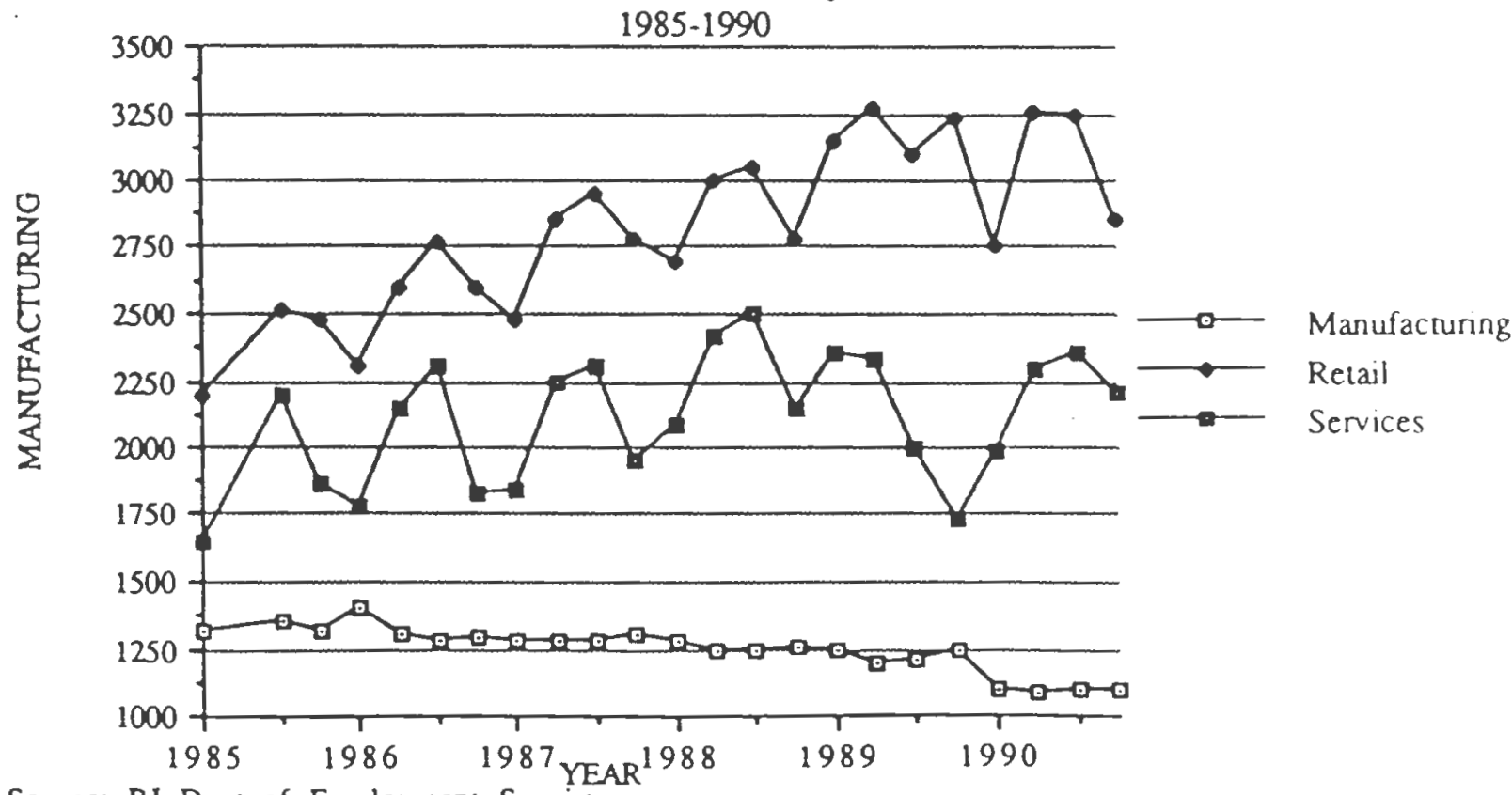

Source: RI Dept of Employment Secuiny 
4) The economic development planner should evaluate the relationship between Westerly's local economy and the Foxwood gambling casino expansion. One of the more recent issues to develop in Westerly is the potential benefit to Westerly's economy derived from the casino expansion. There is little doubt that the casino will have an impact on the Town, however, if an analysis of the effects are studied, perhaps the town can take advantage of the expansion. An example is by the rezoning of areas for development of hotels and institutional uses. 


\section{BIBLIOGRAPHY}

Avery, T. Eugene (1969) Forester's Guide to Aerial Photo Interpretation. ( U. S. Department of Agriculture Handbook \#308, Washington, DC, Government Printing Office)

Banai-Kashani, A. R. "Dealing with uncertainty and fuzziness in development planning: a simulation of high-technology industrial location decision of high-technology industrial location decisionmaking by the analytic hierarchy process". Environment and Planning A v22 p1183-203 September '90

Brooks, R. Gene (1988) Site Planning - Environment. Process and Development (Englewood Cliffs, NJ: Prentice Hall)

Burnell, James D., "Industrial land use, externalities, and residential location" Urban Studies v22 p399-408 October '85

Caminos, Horatio and Reinhard Goethert (1978) Urbanization Primer (Cambridge, MIT Press)

Carter, Larry W. (1977) Environmental Impact Assessment (New York, McGraw-Hill)

Clayton C., N. Simons and M. Mattews (1982) Site Investigation 
(New York: Halsted Press)

Colley B. C., (1986) Practical Manual of Site Development

(New York, McGraw-Hill Book Company)

Cook Wayne C. and Charles D. Bonham (1977) Techniques for

vegetation measurements and Analysis for Pre- and Post

- Mining Inventory (Colorado State University

Experiment Station)

Davidson, Donald A., (1980) Soils and Land Use Planning (London, Longman Group)

Erichson, Rodney A. and Michael Wasylenko. "Firm Relocation and Site Selection in Suburban Municipalities", Journal of urban Economics, 8 (1980, 69-85)

Hewitt, Ralph (1972) Guide to Site Surveying (London, Architectural Press)

Hoare, Antony G., "What do they make, Where, and does it matter any more? Regional industrial structures in Britian since the great war". Geography v71 p289-304 October '86 
Hopkins, Lewis D., (1977) Methods for Generating Land Suitability Maps: A Comparative Evaluation. (Journal of the American Institute of Planners, v. 43, no. 4, pp. 386-400)

Joyce, Michael D. (1982) Site Investigation Practice (New York: E. \& F.N. Spon)

Kuchler, A. W. (1977) Vegetation Mapping, (New York: Ronald Press Company)

Lochmoeller, Donald C., et al, (1978) Industrial Development Handbook, (Washington, DC, Urban Land Institute)

Landpair, Harlow C. and John L Motlach (1985) Site Reconnaissance and Engineering - an Introduction for Architects, Landscape Architects and Planners, (New York: Elsevier)

Lynch Kevin and Gary Hack (1984) Site Planning, (Cambridge, MIT Press)

McHale, John.(1980) The Ecological Context. (New York: George Braziller)

Rubenstein, Harvey M. (1987) A Guide to site and Environmental Planning - Third Edition (New York: John Wiley \& Son) 
Schmenner, R. W. (1978) The Manufacturing location decision evidence from Cincinati and New England. Report of the Economic Research, Economic Development Administration, U.S. Department of Commerce

Stafford, Howard A. (1980) Principles of Industrial Facility Location (Atlanta: Conway Publications, Inc).

Webber, Michael J. "Industrial Location" review by Semple, R. Keith, The Canadian Geographer v29 p279-80 Fall '85

Town of Westerly Comprehensive Plan 1991

Community Monograph, Town of Westerly, 1991

Consultants

Vincent K. Harrington, Rhode Island Department of Economic Development, Research Division

Dr. Robert Griffith, Rhode Island Strategic Planning Division Walter Nepiker, The Rhode Island Historical Society

Thomas Conboy, Rhode Island Department of Transportation 
APPENDIX A

LIST OF PROPERTY OWNERS 
SITE NUMBER FOUR

\begin{tabular}{|l|l|l|l|l||}
\hline PLAT & LOT & ZONING & ACRES & OWNER \\
\hline \multicolumn{5}{||}{} \\
\hline 50 & 9 & M 1 & 6.16 & Josheph Algiere \\
\hline 50 & 11 & M 1 & 12.10 & Marshall Anderson \\
\hline 50 & $11 \mathrm{~A}$ & R30 & 2.48 & Evelyn Anderson \\
\hline 50 & $11 \mathrm{~B}$ & R30 & 1.88 & Thomas Algiere \\
\hline 60 & 23 & M 1 & 2.28 & Clayton Brayman \\
\hline 61 & 1 & R40 & 61 & Antony Algiere \\
\hline
\end{tabular}

SITE NUMBER FIVE

\begin{tabular}{||l|l|l|l|l||}
\hline PLAT & LOT & ZONING & ACRES & OWNER \\
\hline 101 & 1 & A 1/R30 & 4.98 & Narragansit Electic \\
\hline 101 & 2 & A 1 & 110 & Charles Panciera \\
\hline 102 & 1 & A 1 & 40.66 & Al-Jo Realty Company \\
\hline 102 & 3 & R30 & 72.00 & Cosmo Manfredi \\
\hline 111 & 41 & CII & 7.1 & Norman Lagerstrom \\
\hline 111 & $42 \mathrm{~A}$ & PVD & 6.14 & Norman Lagerstrom \\
\hline
\end{tabular}


SITE NUMNBER ONE AND TWO

\begin{tabular}{||l|l|l|l|l||}
\hline PLAT & LOT & ZONING & ACRES & OWNER \\
\hline 39 & 36 & M1 & 56.58 & Salvatore Scavello \\
\hline 88 & 42 & B2 & 84.80 & Alfred Carpionator \\
\hline
\end{tabular}

SITE NUMBER THREE

\begin{tabular}{|l|l|l|l|l||}
\hline PLAT & LOT & ZONING & ACRES & OWNER \\
\hline \multicolumn{5}{|||}{} \\
\hline 98 & 9 & R15 & 17.22 & Joseph Zanella \\
\hline 107 & 85 & R15 & 33.36 & Cyril Morre, Vest est. of \\
\hline 107 & 86 & R15 & 2.04 & Lillian M. Ruisi \\
\hline 107 & 88 & R15 & 77.78 & Joseph Silver \\
\hline
\end{tabular}

